حَوْليَّةَة سِمِنَارِ التَّاريخِ الإسهاميِّ والوسيط

1 


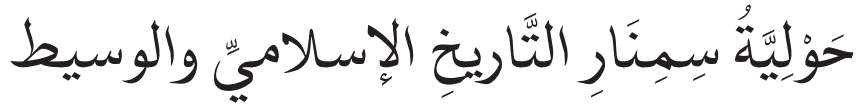 \\ مجلة سنوية محكمة تعني بالتاريخ الإسلامي والوسيط \\ يصدرها سمنار التاريخ الإسلامي والوسيط \\ بالجمعية المصرية للدراسات التاريخية}

$$
\text { للهيئة المصرية العامة للكتاب حفوظة }
$$

$$
\begin{gathered}
\text { رقم الإيداع بدار الكتب } \\
\text { INVO. }
\end{gathered}
$$

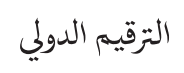

$$
\text { pr. |N/s| }
$$

قطعة § بلوك V ـ المنطقة التاسعة ـ شارع د. رؤوف عباس ـ مدينة نصر ـ القاهرة ت r

Email: Seehist1995@yahoo.com 


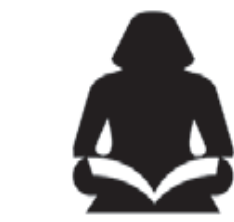

الهيئة المصرية العامة للكتاب

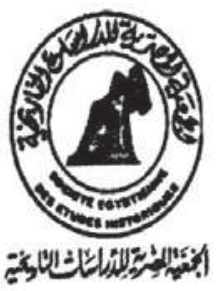

$$
\text { حَوْلِيَّةُ سِيَنَارِ }
$$

$$
\begin{aligned}
& \text { تُصْدرها } \\
& \text { الجمعية المصرية للدّراسات التاريخية } \\
& \text { المراسلات : الأستاذ الدكتور أيمن فؤاد سيد } \\
& \text { رئيس مجلس إدارة الجمعية المصرية للدراسات التاريخية }
\end{aligned}
$$

العدد السادس

$$
\text { القاهرة }
$$




$$
\text { رئيس ججلس الإدارة أ. د/ أيمن فؤاد سيد }
$$

$$
\begin{aligned}
& \text { الهيئة الاستشارية } \\
& \text { هيئة التحرير } \\
& \text { رئيس التحرير أ. د/ حسين عبد الله مراد أ.د/ إسحق تاوضروس عبيد }
\end{aligned}
$$

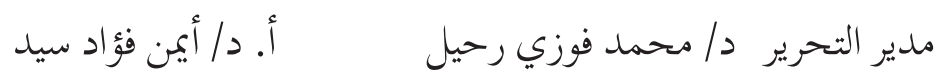

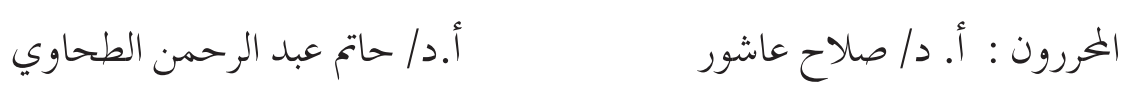

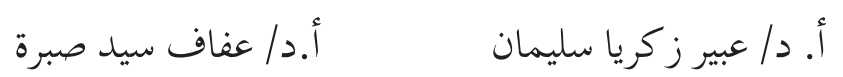

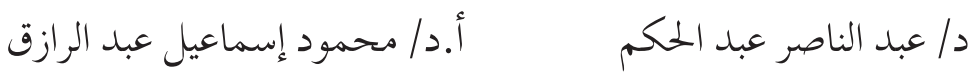

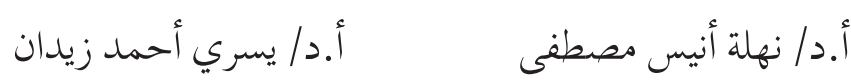

$$
\begin{aligned}
& \text { الآراء الواردة بهذه المجلة تعبر عن وجهة نظر أصحابها ، } \\
& \text { ولا تعبر بالضرورة عن وجهة نظر الجمعية أو السمنار أو الناشر لأشراك }
\end{aligned}
$$




\section{شروط النشر}

ـ أن يكون الباحث عضوًا في الجمعية المصرية للدراسات التاريخية .

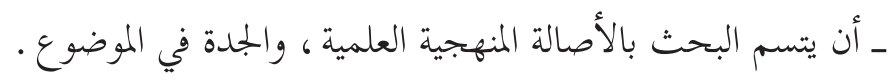

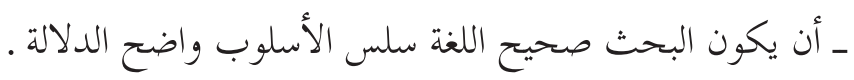

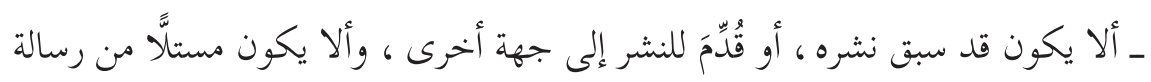
علمية . ـ ألا تزيد صفحات البحث عن ·ب ورقة .

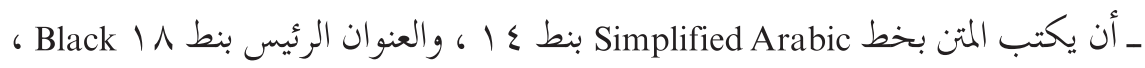

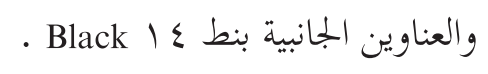

ـ الحواشي:

= الحواشي العربية بنط r Simplified Arabic المسب النظام المعمول به في هذا

$$
\text { العدد. }
$$

= الحواشي اللاتينية بنط • Times New Roman حسب النظام المعمول به في هذا

$$
\text { العدد. }
$$

ـ أن تذكر المعلومات الببلوجرافية للمصادر والمراجع كاملة عند أول ذكر لها في الحواشي، الماثل

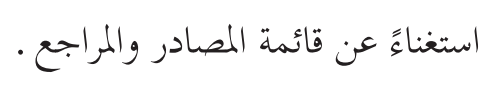

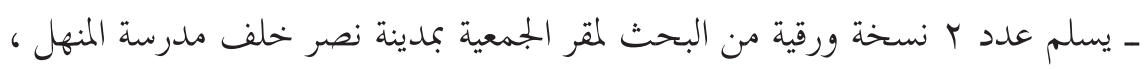

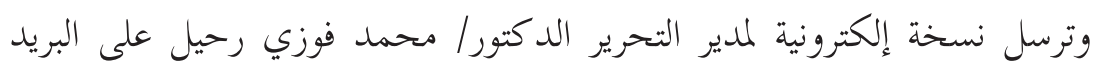

$$
\text { raheela2010@gmail.com الإلكتروني }
$$

ـ تحكيم البحوث يكون مِرِيَّاً ، بمعرفة هيئة تحرير المجلة . 

بسم الله و الصلاة و السلام على رسول الله وآله وصحبه ومن والاه ـ يسعد هيئة تحرير

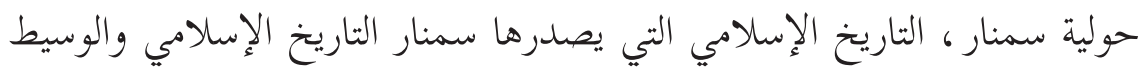

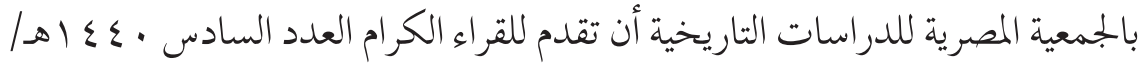

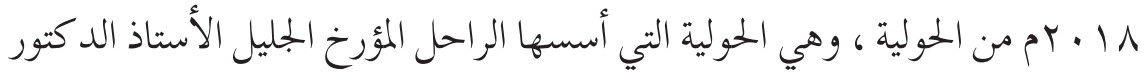

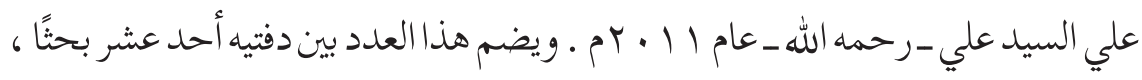
تطوف بنا عبر فرعَي التاريخ الإسلامي والوسيط؛ إذ يلحظ المطالع لبحوث العدد تنوع

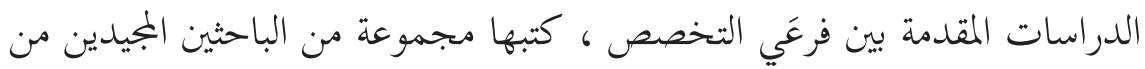

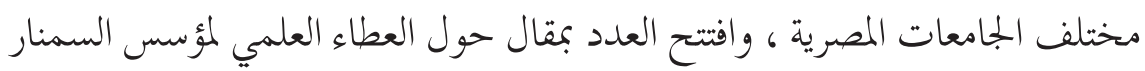

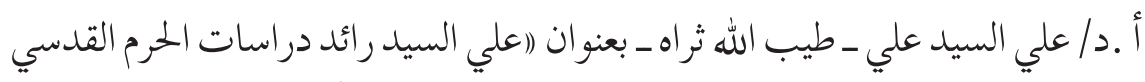

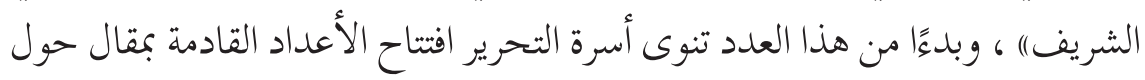
سيرة أحد رواد تخصص التاريخ الإسلامي والوسيط الراحلين أملاً في حفظ سير هؤلاء

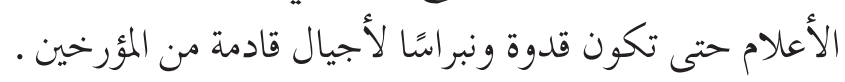
وترحب أسرة السمنار بالمتخصصين في التاريخ الإسلامي والوسيط للمشار كة في

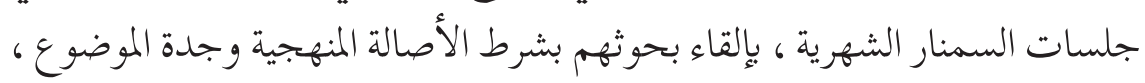

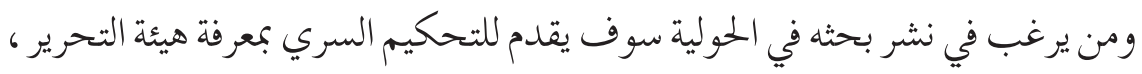

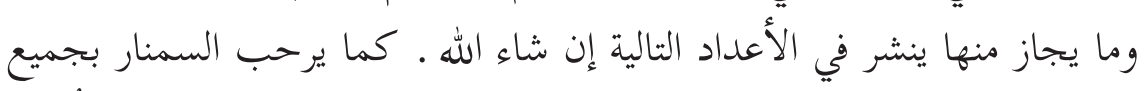

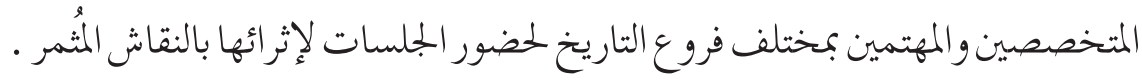
ويطيب لأسرة التحرير تقديم أسمى آيات الشكر والتقدير لمجلس إدارة الجمعية برئاسة

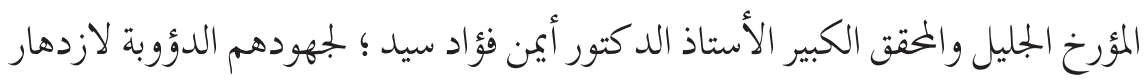
الجمعية المصرية للدراسات التاريخية لتظل في صدارة الجمعيات التاريخية العربية . والله من وراء القصد والهادي إلى سواء السبيل،6،6،6، ك،

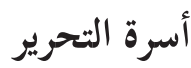





\section{المحتـويات}

$$
\begin{aligned}
& \text { الصفحة } \\
& \text { على السيد علي رائد دراساتُ الحرمِ القدسيّ الشريف فحمِ فحيف } \\
& \text { محمد فوزي رحيل . } \\
& \text { أسرةُ ثيوفلاكت ودورُها السياسيُّ والدينيُّ في روما فحري }
\end{aligned}
$$

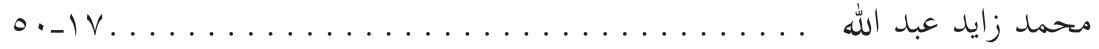

$$
\begin{aligned}
& \text { مكتباتُ الأديرة في ضوْيُ التيبيكا البيزنطية }
\end{aligned}
$$

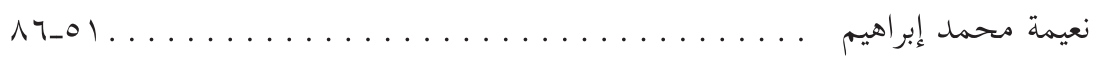

$$
\begin{aligned}
& \text { سفاراتُ العلمايِ في العصرينِ الغزنويِّ والسلجوقيِّ } \\
& \text { مرفت رضا . }
\end{aligned}
$$

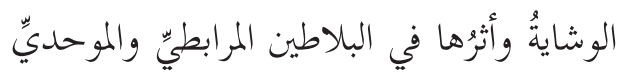

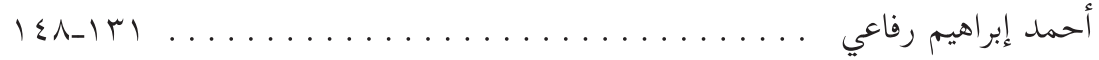

$$
\begin{aligned}
& \text { دولةُ الخُطَا في الصينِ وتركستانَ وكرمانَ }
\end{aligned}
$$

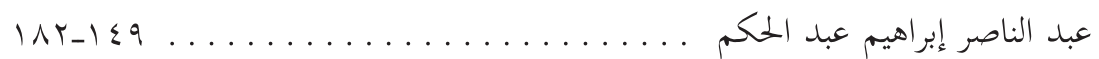

$$
\begin{aligned}
& \text { ادعاءُ النبوةِ في مصر والشام عصر سلاطيِن المماليكِ } \\
& \text { محمود عبد المقصود ثابت ل........................ } \\
& \text { الكلابزيةُ في عصرِ سلاطِِِ المماليكِ } \\
& \text { أحمد عبد الله أحمد . . . . . . . . . . . . . . . . . . . } \\
& \text { قراءةُ الجوقِ وقراؤها في مصَر خلال القرنينِ م-ههـ }
\end{aligned}
$$

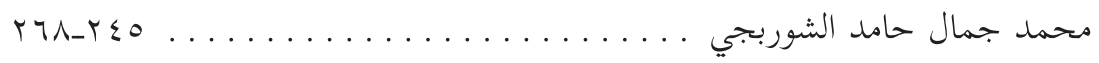

$$
\begin{aligned}
& \text { المجددونَ والتاريخُ الإسلاميّ (الإمام محمد عبده نموذيجًا) }
\end{aligned}
$$

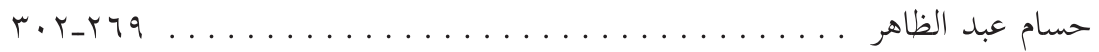


حَوْيَيَّة سِمِنَارِ الثَّاريخ الإسلاميَّ والوسيط

1.

صورةُ صلاحِ الدينِ في السينما الغربيةٍ بينَ الحقيقِِ والحيالِ

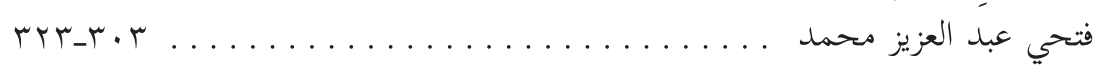




\section{مكتبات الأديرة في ضوء التيبيكا البيزنطية}

(وثائق تنظيل/ت الأديرة)

من القرن السابع الميلادي إلى القرن الرابع عشر الميلادي

نعيمة محمد إبراهيم

التيبيكا Tipika البيزنطية ، هي وثائق تتضمن القواعد واللوائح المنظمة للحياة

داخل الأديرة البيزنطية ، وتحتوي على معلومات مهمة عن طبيعة حياة الرهبان داخل الدير و كيفية سيرها ، و كذلك النظم الإدارية والطقوس الدينية داخل الأديرة

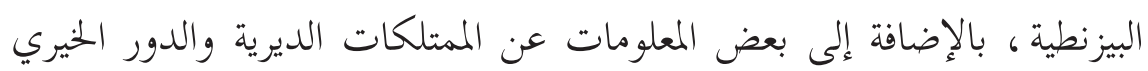

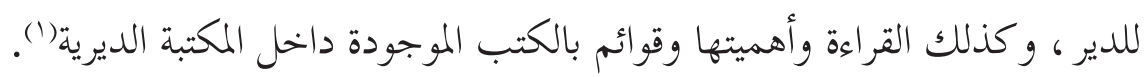
وقد بدأ الاهتمام بجمع وثائق الأديرة البيزنطية وترجمتها في فترة مبكرة من ون

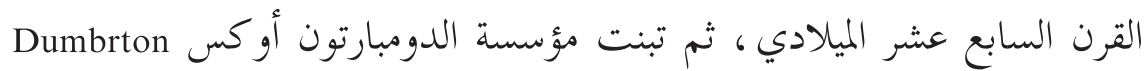
Oaks Center

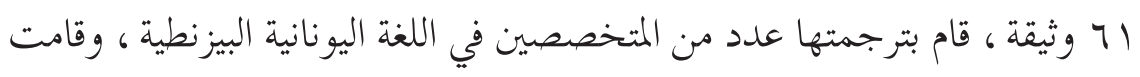

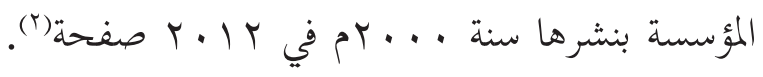

(1) ODB, 3, p.2132.

(2) Thomas, J. and. Hero, A.C., (eds). Byzantine Monastic Foundation Documents, A Complete Translation of the Surviving Founders Typika, washington D.C. 2000, pp.1-13. 
وقد قمت باختيار هذا الموضوع ، وهو : (مكتبات الأديرة في ضوء التيبيكا

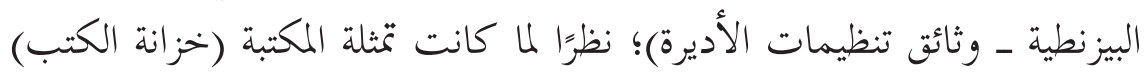
ومكونها الأساسي وهو الكتاب ، و كذلك القراءة من دور مهم وأساسي في حيات التهات

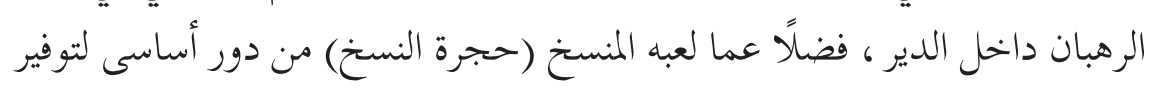

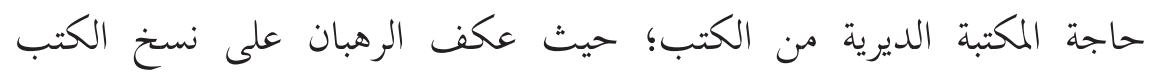

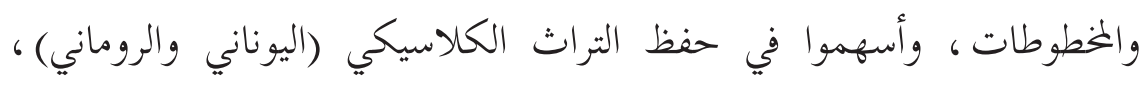
و كتابات آباء الكنيسة وحمايتها من الضياع فى فترات الاضطر ابات ، وات وهي النصوص

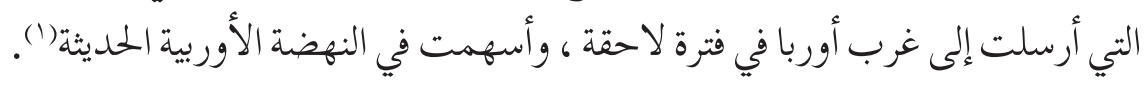
ومن هنا أخذت في قراءة التيبيكا الديرية وجمع المعلومات المتناثرة بين صفحاتها

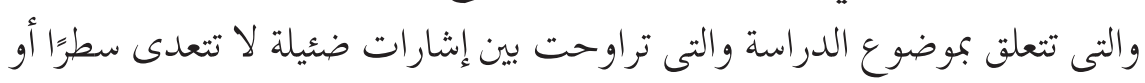

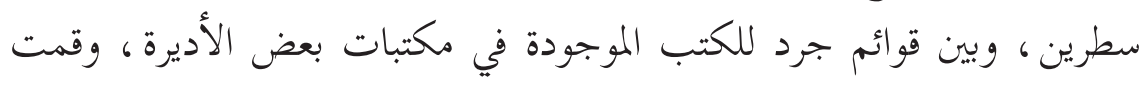

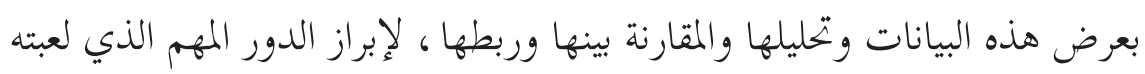
المكتبات الديرية في الحياة الثقافية البيزنطية.

\section{أهمية القراءة ووجود المكتبة بالدير}

لقد بدأت المكتبات الديرية منذ بداية ظهور الرهبنة الجماعية المنظمة على يد

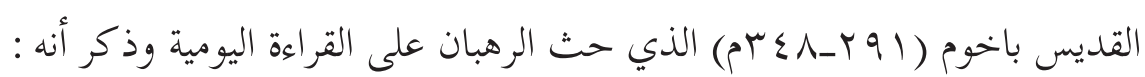

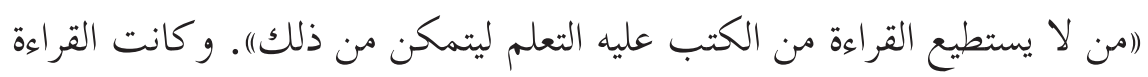

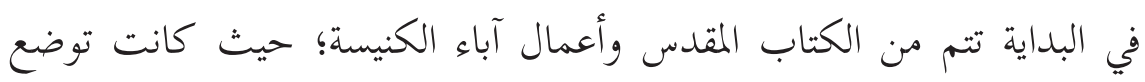
الكتب والمخطوطات في صناديق خاصة داخل أسوار الدير(r)؛ إذ كان الكناء الكتاب هو

(1) PAdover. S.K., «Byzantine Libraries», in: The Medieval Library, ed. Thompson, J.W., New York, London 1967, p.311.

(2) Herman, A. Peterson, «The Genesis of Monastic Libraries», L \& CR vol. 45, No. 3 (2010), p.328 
الصديق الوفي للرهبان منذ الفترة المبكرة للحياة الديرية، وذلك لتدعيمهم ومساندتهم في عزلتهم، و ولإشباع نهمهم وشغفهم الروحي العميق ، وإمدادهم

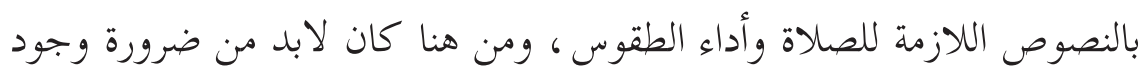
مكتبة بداخل كل دير (1).

وقد ذكر أحد الرهبان أهمية وجود المكتبة بالدير قائلاً : (إن الدير بدون مكتبة

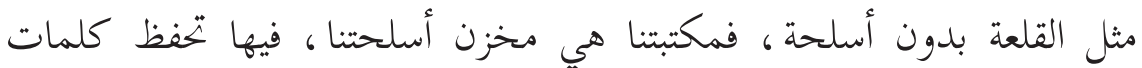

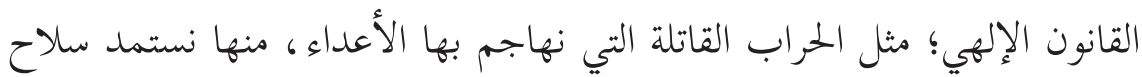
الحق ، وخوذة الخلاص، ، ودرع الإيمان ، وسيف الروح الذي هو كلمه الله)|(r).

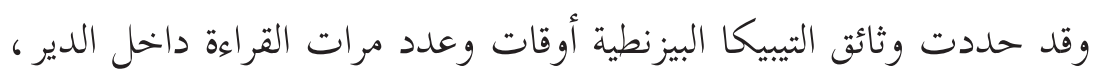
فذكرت تيبيكا دير نيلوس دماليس Neilos Damilas لأكثر من مرتين يوميًا ، واعتبرتها عبادة مساوية للصالاة (الفالصلاة والقراءة

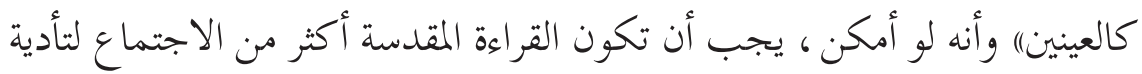

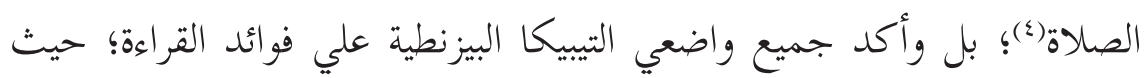

(1) Staikos, Konstantios, Sp., The History of the Library in Western Civilization from Constantine The Great to Cardinal Bessarion Imperial, Monastic, School and Private Libraries in The Byzantine World, Kotinos 2007, p.246.;

Charnis, Peter, «The Monks as an element», DOP vol. 25 (1971), p.80.

(r) نقلًا عن : شعبان خليفة ، الكتب والمكتبات في العصور الوسطى ، القاهرة ـ الدار المصرية اللبنانية

.rYV:1 619VV

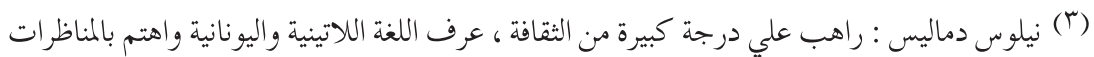

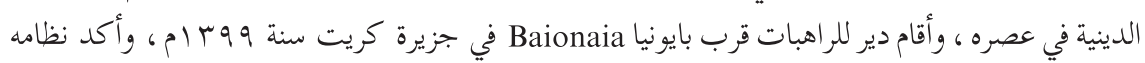

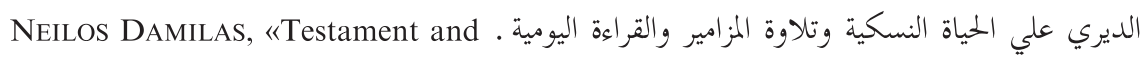
Typikon of Neilos Damilas for The Convent of The Mother of God Pantanassa at Baionaia on Crete», Trans. Talbot, Alice-Mary, BMFD 54, p.1462, ODB, I, p.581.

(4) Neilos Damilas, p.1475. 
ذكروا أن الإنسان: (الا يستطيع العيش بالخبز وحده)) ، وإنما لابد من القراءة

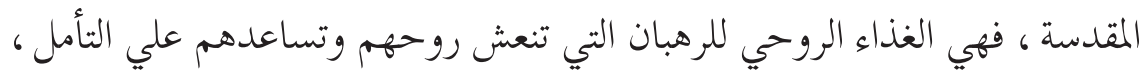

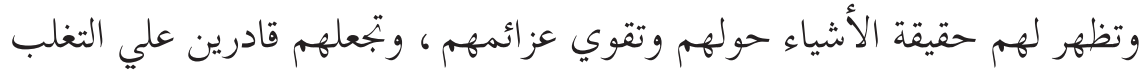

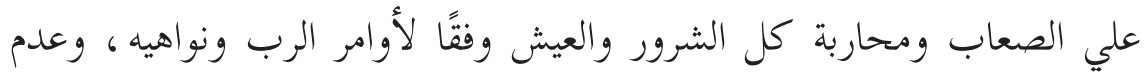

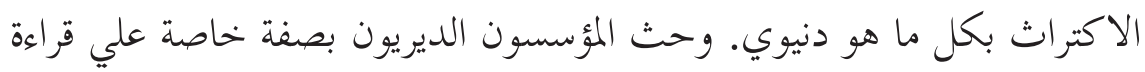
سير القديسين والقديسات؛ لأنها تشجع الرهبان علي أن يسلكوا طريقهم القويم في (1) الحياة ويتبعوا خطاهم المديسن

لقد كانت القراءة جزءًا لا يتجزأ من حياة الرهبان اليومية ، وعملاً مصاحبًا

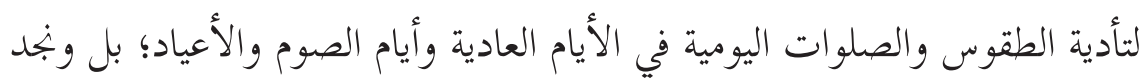
التيبيكا تحدد الأجزاء التي يجب ان تتم قراءتها في كل وقت من صلوات الصباح

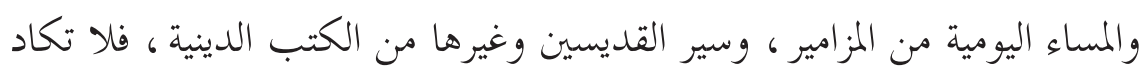

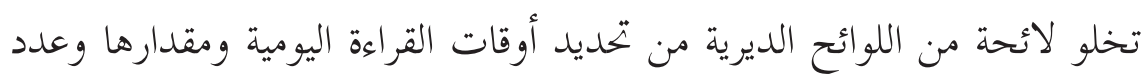

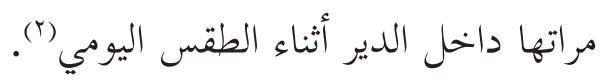
لم تقتصر القراءة داخل الأديرة البيزنطية علي القراءة المصاحبة للصلاة وتأدية

(1) Charsianeites, «Testament of patriarch Matthew I For The Monastery of Charsianites Dedicated to The Mother of God Nea Peribleptos», Trans, Talbot, Alice-Mary, BMFD, p.1658.; Evergetis, «Typikon of Timothy For The Monastry of The Mother of God Evergetis», Trans. Jordan, Robert, BMFD, pp.496-7; BEBAIA ELPIS, «Typikon of Theodora Synodene For The Convent of Mother of God Bebaia Elpis in Constantionple», Trans. Talbot, Alice-Mary, BMFD 57, pp.1515-1548; Cameron, Averil, The Byzantines, London 2006, p.153.

(2) KARYES, «Typikon of Sabbas The Serbian For The Kellion of St. Sabbas at Karyes on Mount Athos», Trans. Dennis, George, BMFD, 44, pp.1334-1335; BLACK MountAIN, «Regulations of Nikon of The Black Mountain, Trans, Allison, Robert», BMFD, 20, Washington 2000, p.390; Stoudios, «Rule of The Monastery of St. John Stoudios in Constantinople», Trans. Timothy, Miller, BMFD 4, Washington 2000, p.622. 
الطقوس اليومية فقط؛ وإنما حُث الرهبان علي القراءة في أوقات فراغهم وعندما لا

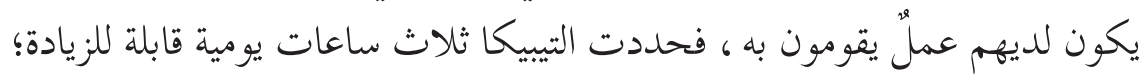
خاصة في أيام الصيف عندما تكون ساعات النهار أطول؛ أما في ليالي الشتاء

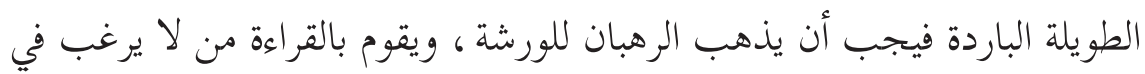
العمل اليدوي، وبعد الانتهاء يذهبون إلي صوامعهم (1). بالإضافة للقر اءة السابقة التي يقوم بها الرهبان أنفسهم؛ فقد كانو ايستمعون للقر اءة

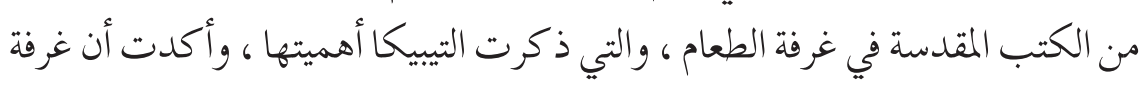

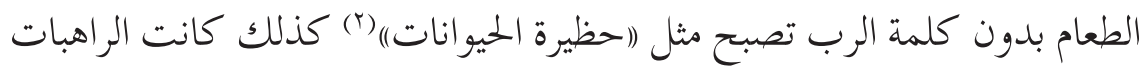

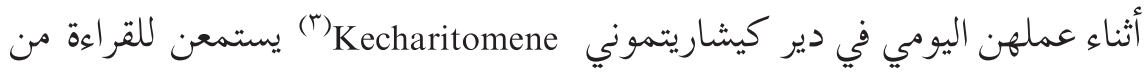
الكتب المقدسة ، والتى كانت تحقق لهن السعادة الروحية ، وتخفف عنف عنهن عناء

ونظرًا لأهمية القراءة في حياة الرهبان؛ فقد وضعت التيبيكا نظامًا لها وقواعد

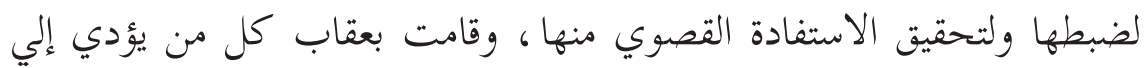
تعطيلها وعدم تحقيقها للفائده المرجوه منها؛ فكانت القراءة تبدأ عادة بأن يقوم أمين

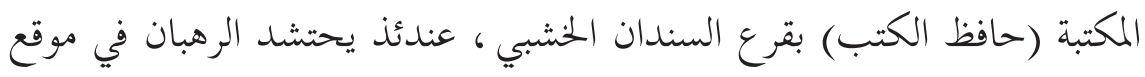

(1) Black Mountain, p.391; Ath. «Rule, Rule of Athanasios The Athonite For The Lavra Monastery», Trans. Dennis, Georg, BMFD, 11, Washington 2000, pp.221223; Bebaia Elpis, pp.1515, 1542; PhILANTHroprs, «Typikon of Irene Choumnaina Palaiologina For The Convent of Christ Philanthropos in Constantinople», Trans. Talbot, Alice-Mary, BMFD, 47, Washington 2000, p 1387; Stoudios, p.232.

(2) Charsianeites, p.1658.

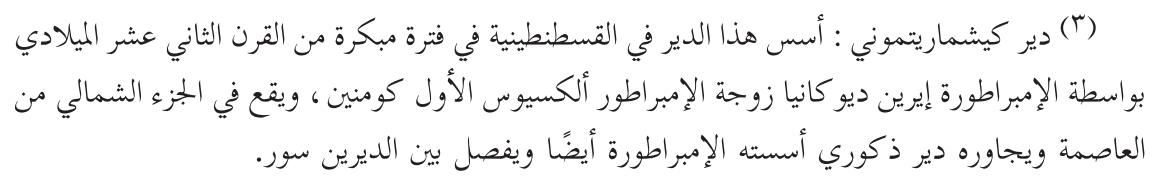

(3) KeChARitomene, pp.685-6. 
الكتب ويأخذ كل واحد منهم كتابا لقراءته ويظل معه حتي الغروب ، عندئذ يقوم

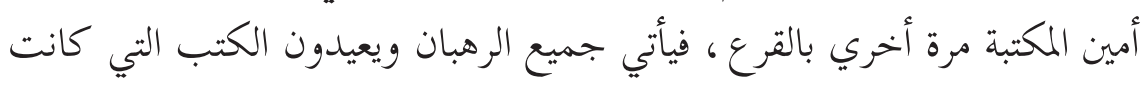
لديهم منذ الصباح (1) أما عن نظام القراءة في غرفة الطعام فقد كانت تبدأ عادة بعد جلوس الرهبان

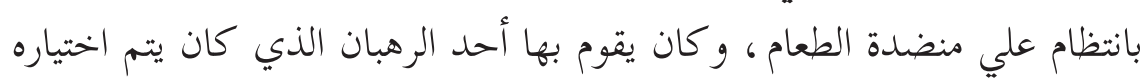

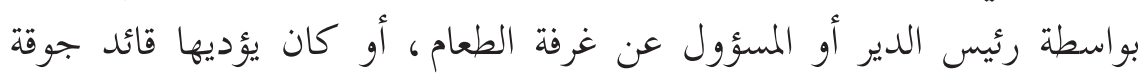

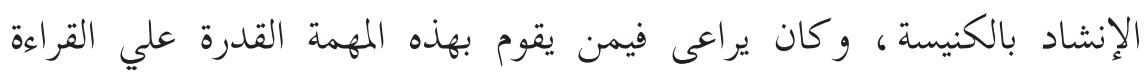

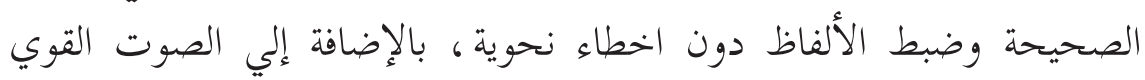
الواضح (r) كذلك فرضت التيبيكا علي الرهبان أثناء القراءة في غرفة الطعام علي ضرورة الاستماع بـ(آذان صاغية) والتفكر والتدبر فيما يُقرأ عليهم مع مراعاة الالتزام

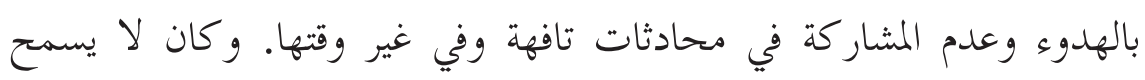

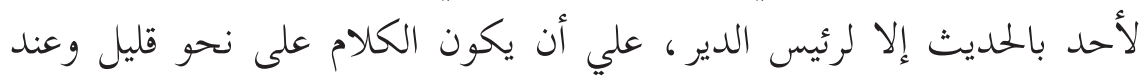

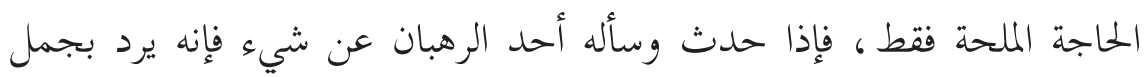

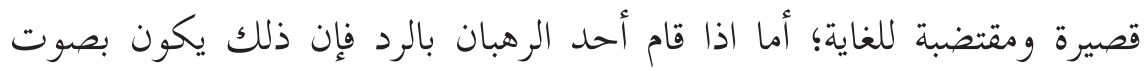
منخفض وعبارات مقتضبة ثم يصمت في الحال ، ولكن إذا حدث إثل وأقدم أحدان

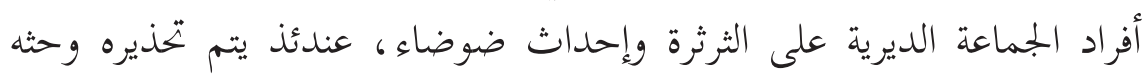

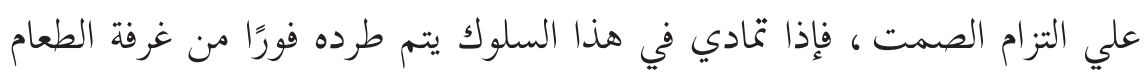

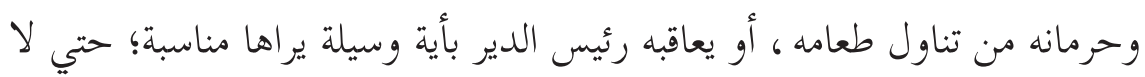

(1) Stoudios, p; Staikos, The Historyof The library, p.190.

(2) LIPS, «Typikon of Theodora Palaiologina For The Convent of Lips in Constantinople», Trans. Talbot, Alice-Mary, BMFD 39, Washington 2000, p.1274; Kecharitomene, pp.683, 685; Black Mountian, p.408; Stoudios, p270; New York 1999, p.33. 
يعود مرة ثانية لهذا السلوك الشائن(1).

علاوة على ذلك قد ألزمت التيبيكا الرهبان عند القراءة في صوامعهم بضرورة

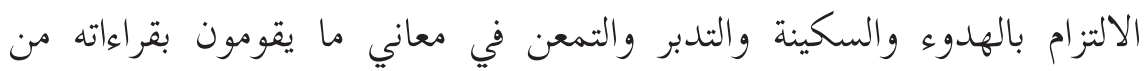

نصوص(r). فضلًا عن ذلك فقد عين مؤسسو الأديرة شخصًا يدعي (الموقظ)

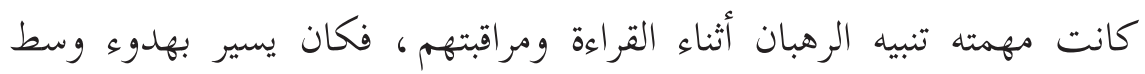

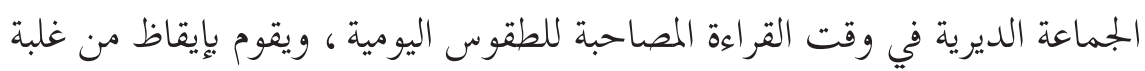
النعاس وحثه علي اليقظة والانتباه(r).

كذلك شددت التيبيكا على ضرورة الاهتمام بالكتاب وعدم إهماله ،

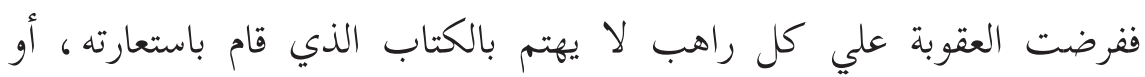

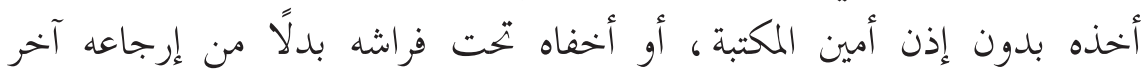

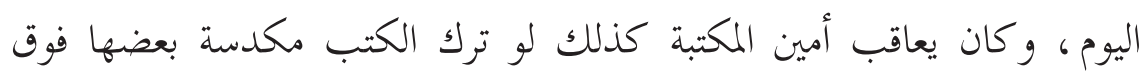

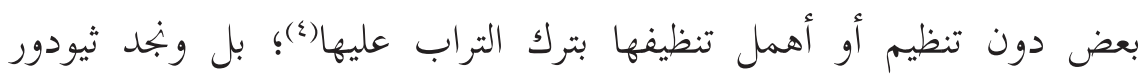

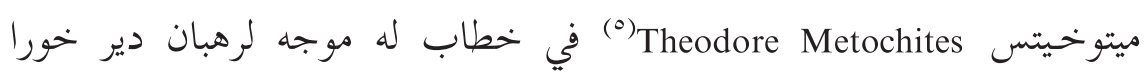

(1) Bebaia Elpis, p.1542; Machairas, «Rule of Neilos, Bishop of Tamasia, For The Monastery of The Mother of God of Machairas in Cyprus», Trans. Bandy, Anastasius, BMFD 34, Washington 2000, p 1142; Evergetis, pp.478-479; Kecharitomene, p.689.

(2) Bebaia Elpis.

(3) Machairas, p.1142; Rule of Athanasios The Athonite, p.225.

(4) Stoudios, ch 26; Staikos, The History of The Library, p.190.

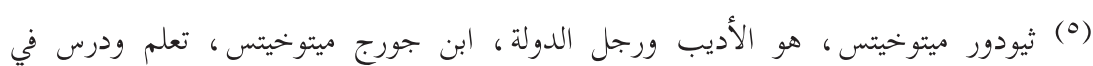

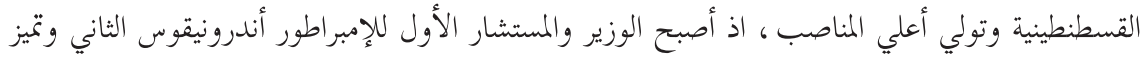

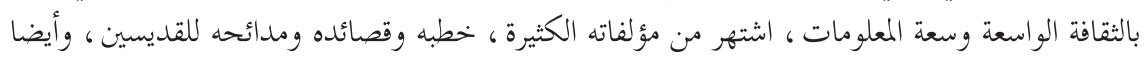

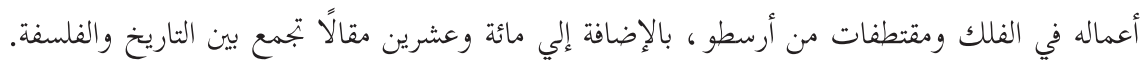

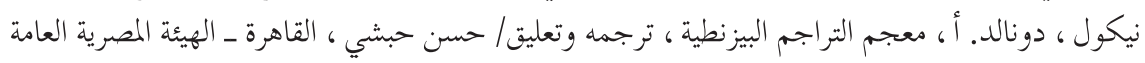


Chora وتنظيفها؛ حتى لا تتلف بالعتة والحشرات(r)، كما ألزمت التيبيكا الإيكليزيارخ Ecclesiarch

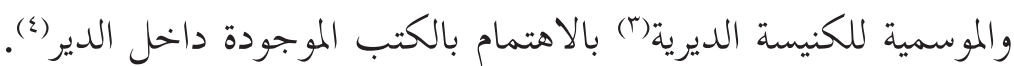

\section{مكان المكتبة داخل الدير}

في البداية يجب أن نشير إلي أن كلمة مكتبة في الفترة محل الدراسة؛ لم يكن

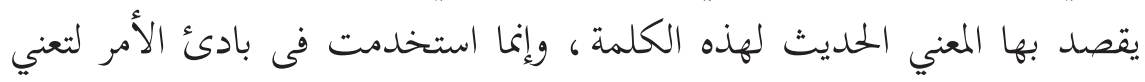
مجموعة الكتب الموجودة داخل أسوار الدير ثم صارت تُطلق علي المكان المحدد الذى توضع فيه هذه الكتب؛ كذلك كانت الكتب منتشرة داخل الدير في أكثر من مكان ، فلم يكن للمكتبة مبني مستقل أو تصميم معماري مميز بها داخل

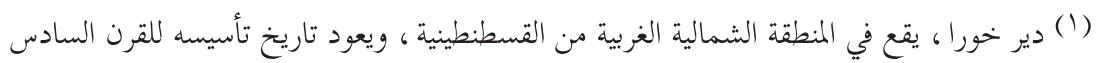

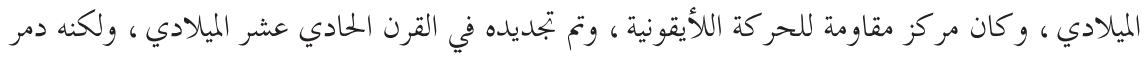

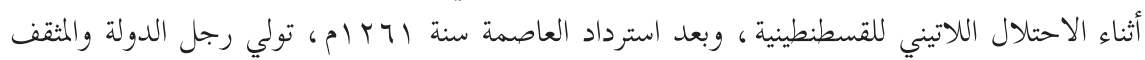

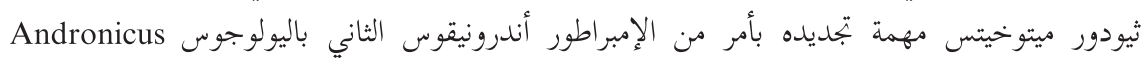
كالكت Palaiologos بالمكتبة بصفة خاصة وزودها بالعديد من الكتب. لمزيد من التفاصيل: SEvcenko, I., «Theodore Metochites, The Chora, and The Intellectual Trends of His Time» in: The Kariye

Djami, ed. Underwood, Paul. A., Princeton 1975; ODB, I, pp.428-30.

(2) Staikos, The History of The library, p.427.

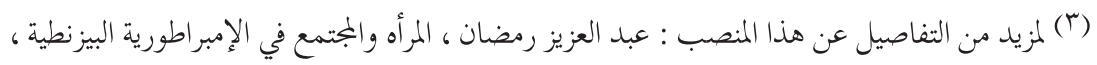

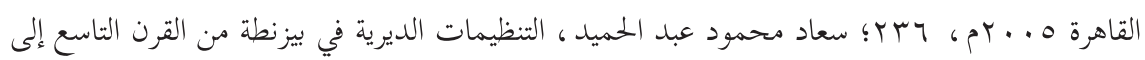

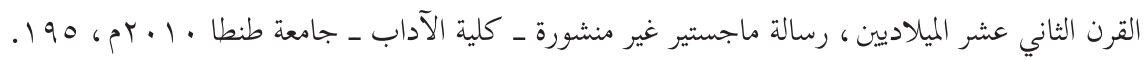

(4) Christodoulos, «Rule, Testament and Codicil of Christodoulos For The Monastery of St. John The Theologian on Patmos, Trans. Karlin-Hayter», Patricia, BMFD 24 Washington 2000, p.589. 
الدير ، وربما كان يرجع ذلك إلي طبيعة الحياة الدينية المسيحية نفسها ، فبعد ظهور

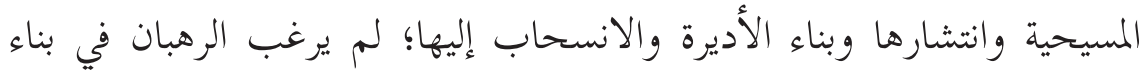

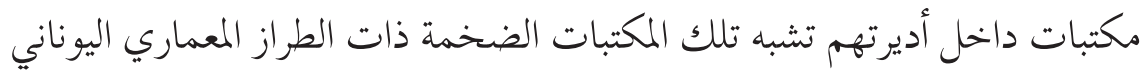

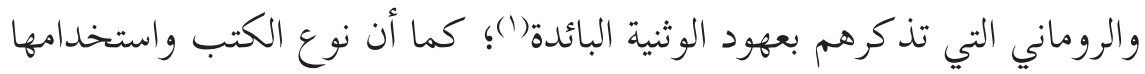

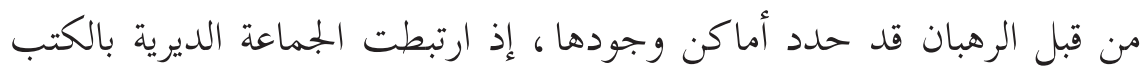

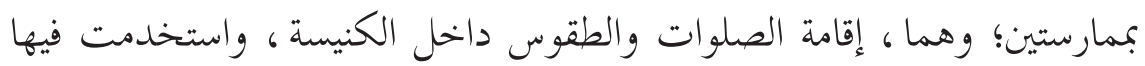

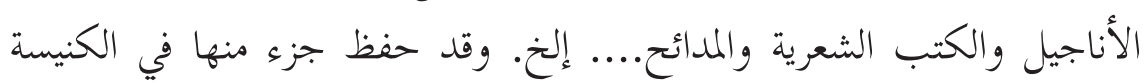
الرئيسية وغرفة المقدسات والمحراب في الحرم المقدس ، في حين أن سير القديسين

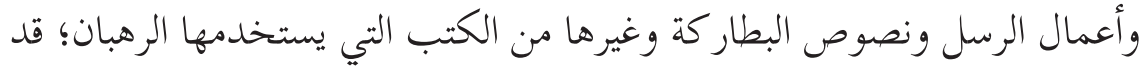

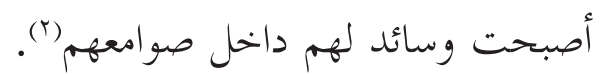
فضلًا عن ذلك كانت الحياة الديرية كتابًا مفتوحًا من المزامير والتلاوات

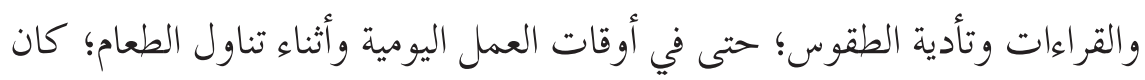

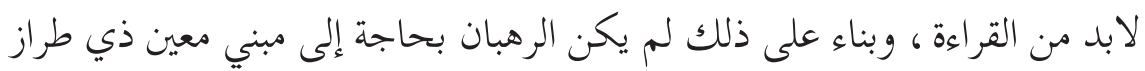

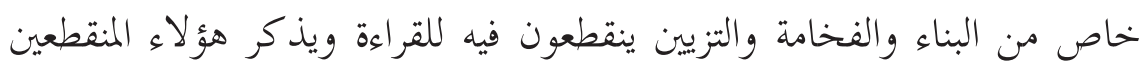

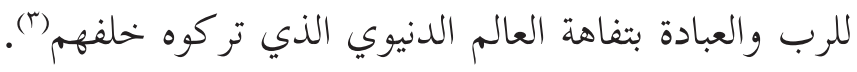

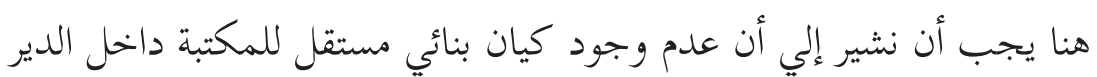

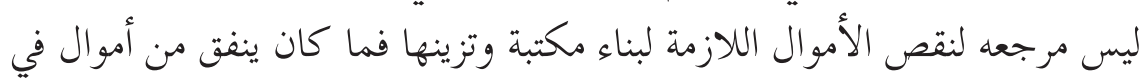

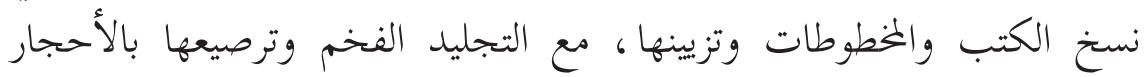

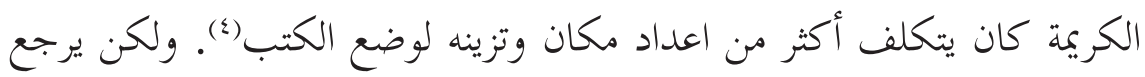

(1) Clark, John. W., The care of Books, London 2007, pp.48-9; Staikos, The History of The library, pp.469-71.

(2) Staikos, The History of The library, p.471

(3) Staikos, The History of The library, p.471.

(4) Staikos, The History of The library, p.471. 
ذلك كله لطبيعية حياة الرهبنة ذاتها والتى كان أساسها التقشف والزهد ، فهؤلاء

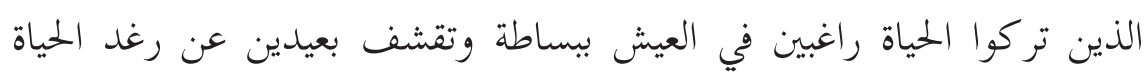

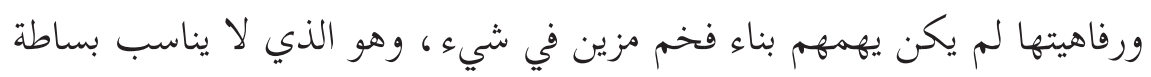

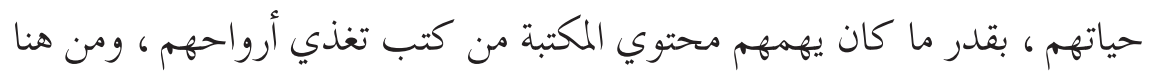

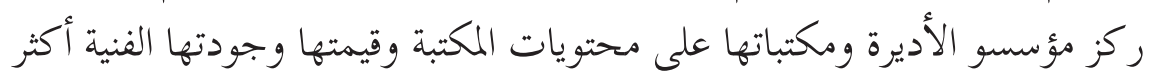

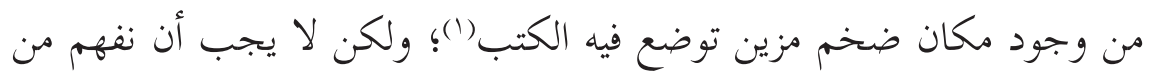

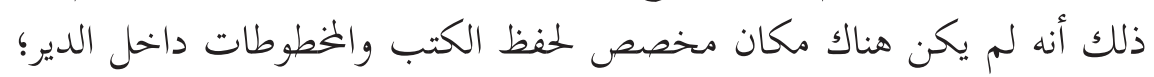
حيث امتلك كل دير الكثير من الكتب التي قامت عليها الحياة الدينية والطقوسية ،

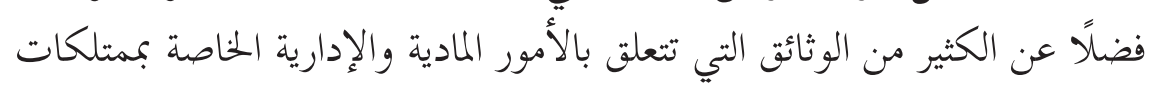

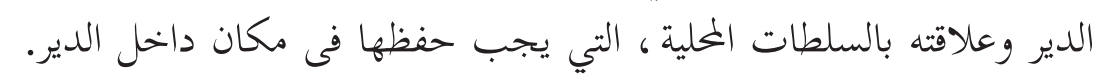
ومن هنا وجدت المكتبة بداخل مباني وحجرات الكنيسة ، وقد كان هذا أمرًا

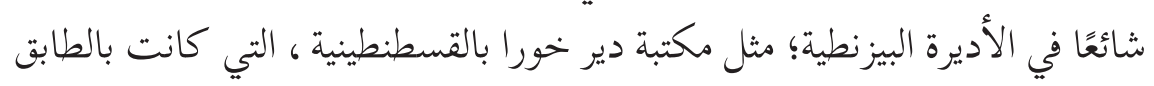

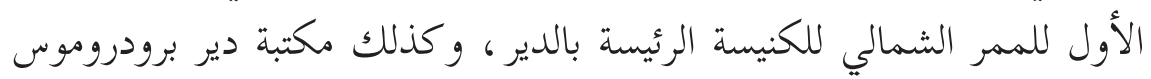
ومكتبات أديرة جبل أثوس Modromos الكنيسة الرئيسة للدير منذ القرن العاشر، فضلًا عن ذلك الك استخدمت الأبر أبراج

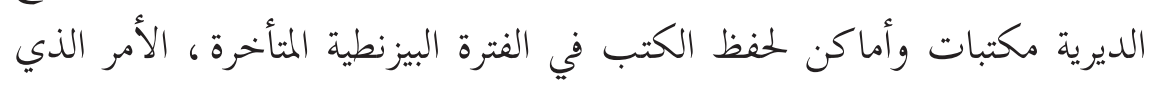

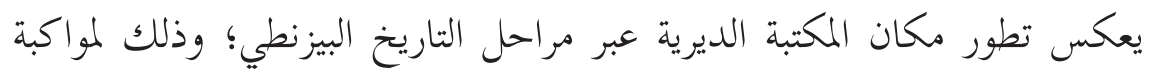

(1) Staikos, The History of The libarary, p471.

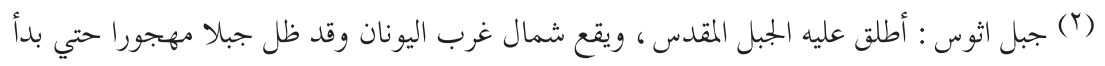

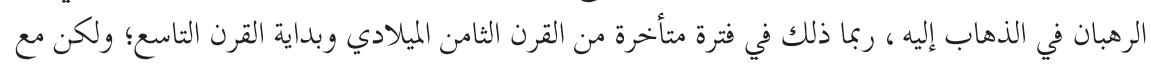

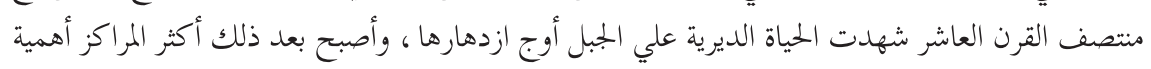

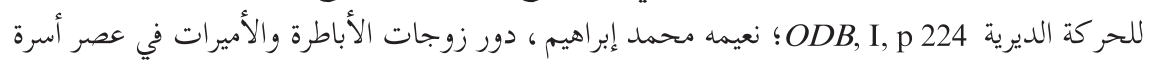

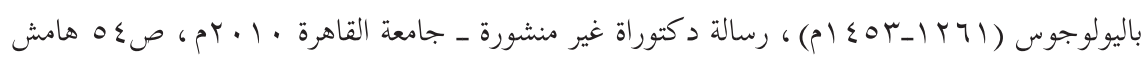

رقم (Г). 
ازدياد أهمية الدور الثقافي والروحي لها، وللزيادة المستمرة في أعداد الكتب؛

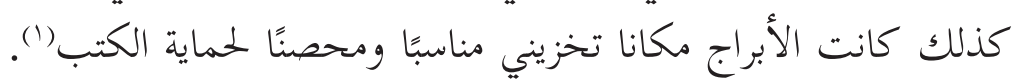

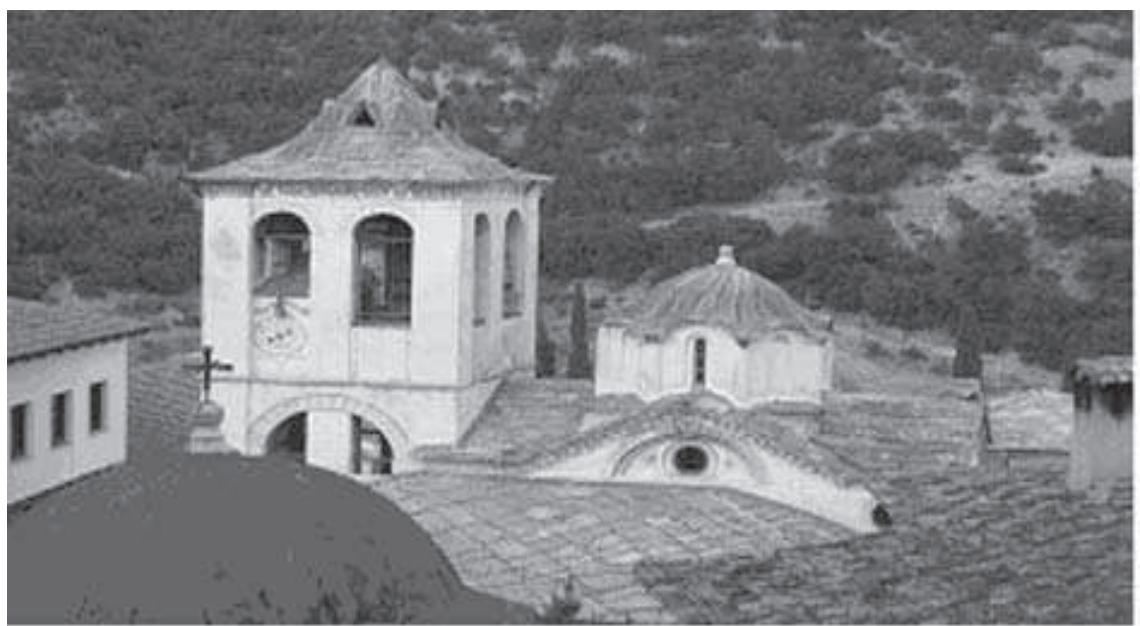

$$
\text { شكل (1) مكان وجود المكتبة بالبرج }
$$

ويري باكيرتزيس Bakirtzis أن وجود المكتبة داخل الكنيسة وأروقتها دليل علي

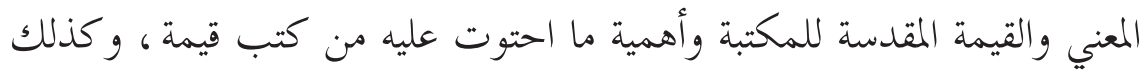
اتصالها الروحي بمؤسسي وزعماء الدير الذين اتخذوا صوامعهم في أروقة

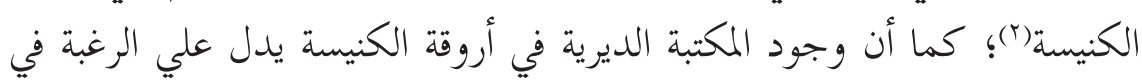

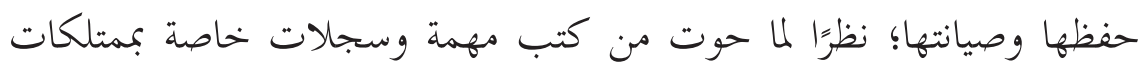

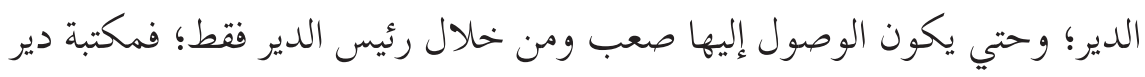

(1) BAKIRTZIS, Nikolas, «Library Spaces in Byzantine and Post-Monasteries» in: Modern Greek Studies Yearbook, Univ. Minnesota, Vol. 22/23, 2006/7 (printed. 2012), pp.41-45; Hagios Ioannis Prodromos Monastery on Mount Menoikeion: Byzantine Monastic Practice, Sacred Topography, and Architecture, PhD, Princeton University 2006, pp.239-254.

(2) BAKIRTZIS, Library Spaces, p.47. 
برودروموس كان الوصول إليها يتم من خلال سلالم قابلة للحمل ، و كذلك بعض مكتبات الأديرة الأخري كان يتم الوصول إليها فقط من خلال ممر ضيق في أعلي مبني الغرفة المجاورة للمكتبة (1)

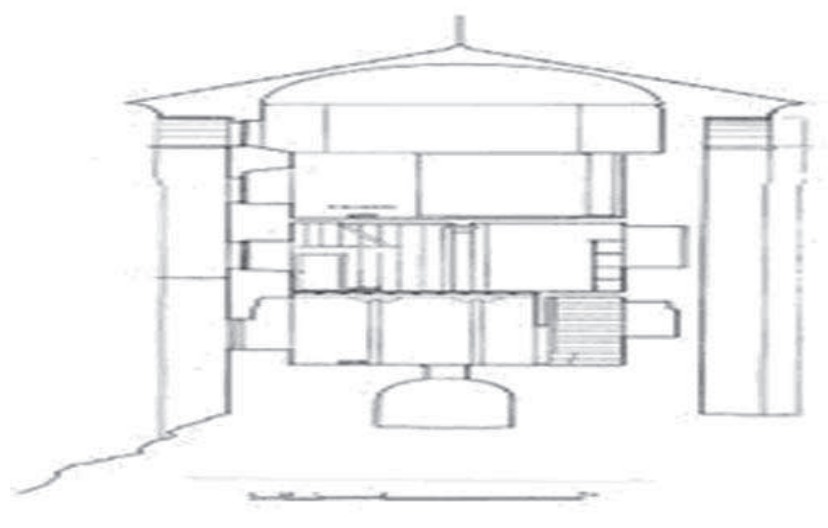

$$
\text { شكل (r) برج المكتبة من الداخل }
$$

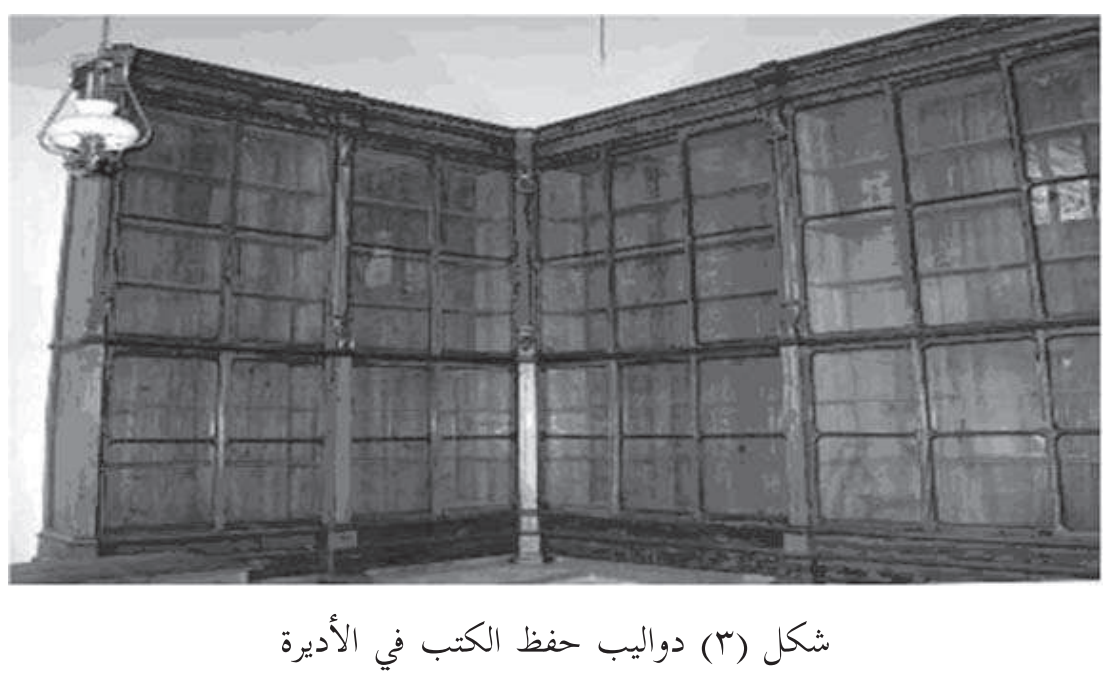

(1) BAKIRTZIS, Library Spaces, p.47. 
وذلك كله من أجل حماية الكتب وصيانتها والذي كان يتم حفظها في

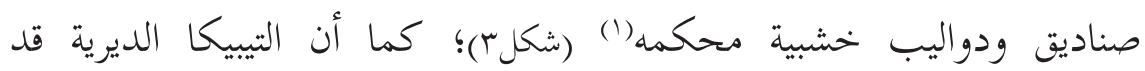
اتخذت إجراءات حازمة لحماية الممتلكات الديرية؛ ومنها الكتب منداء من الاعتداء

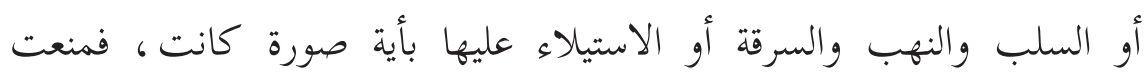

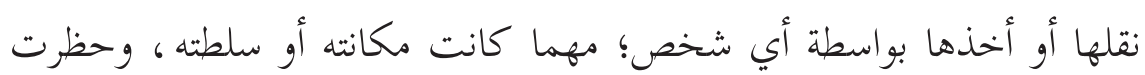
علي رؤساء الأديرة أو أي أحد من الرهبان التصرف فيها تحت أي مسمى ،

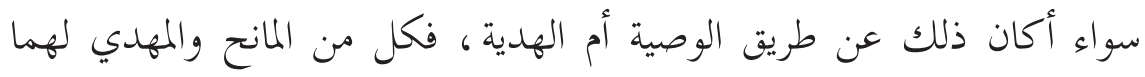

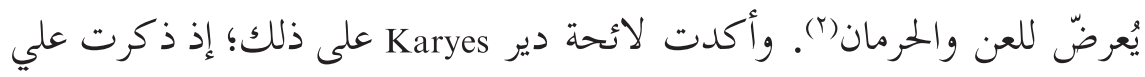

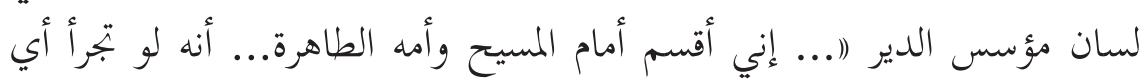

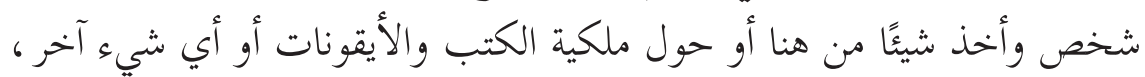

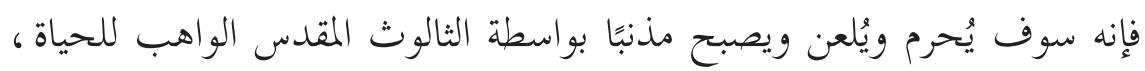

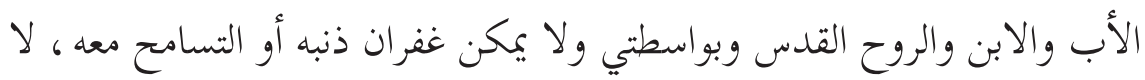

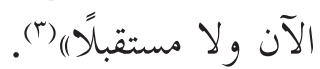

كذلك حرمت التيبيكا علي أفراد الجماعة الديرية إخراج الكتب من الدير أو

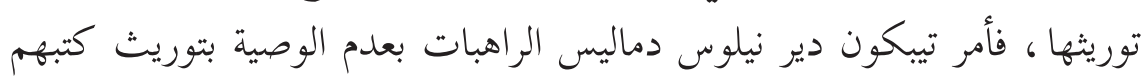

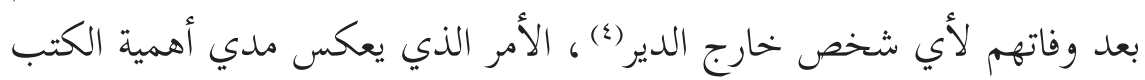
وقدسيتها لدي الرهبان ورغبتهم في الحفاظ عليها.

(1) Staikos, The History of The library, pp.488-9.

(2) Christodoulos. p.599; Evergetis, Machairas, p.1150; «Neophytos, Testamentary Rule of Neophytos For The Hermitage of The Holy Cross near Ktima in Cyprus», Trans. Galatariotou, Catia, BMFD, 45, Washington 2000, p.1355; Phoberos, «Rule of John For The Monastery of St. John The Forerunner of Phoberos», Trans. Jordan, Robert, BMFD 30, Washington 2000, p.37.

(3) KARYES, p.1335.

(4) NeIlos Damilas, p.1470.. 


\section{مصادر حصول المكتبة علي الكتب}

احتوت المكتبة الديرية على عدد مهم من الكتب كان مصدرها في البداية

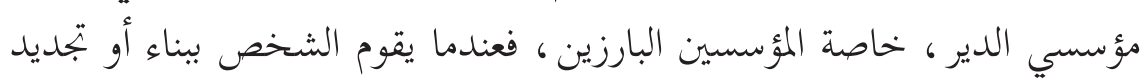

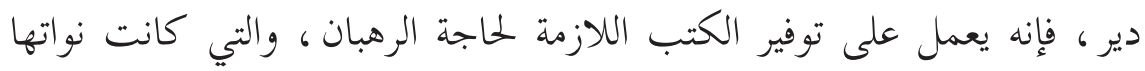

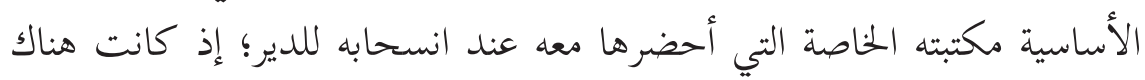

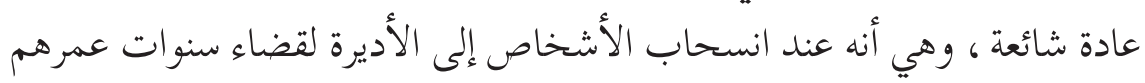

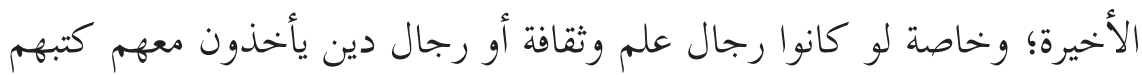

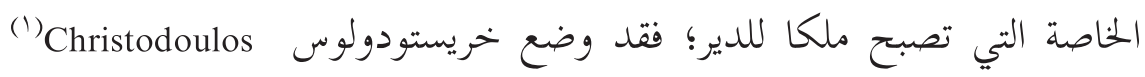
مكتبته في دير باتموس Patmos، وهي المكتبة التي يكشف محتو اهنا عن ثقافة الرجل وحبه للعلم والكتب ، و كذلك أحضر الكثير من الرهبان كتبهم معهم عند بند انسحابهم لهذا الدير(r) كما أن الأميرة ثيودورا رولين Theodora Roulain (ك) (المبة للكتب) قد حملت

(1) خريستودولوس ، ولد في بيثينيا في العقد الأول من القرن الحادي عشر الميلادي ، وبعد أن أصبح

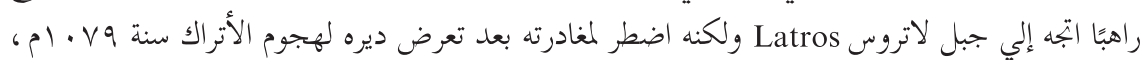

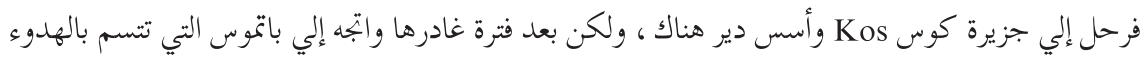

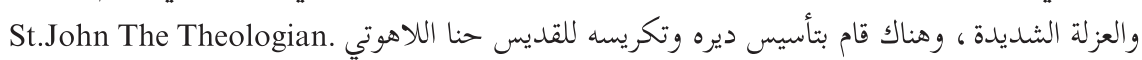

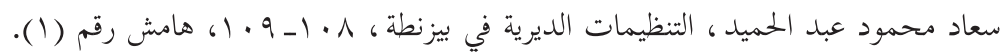
(2) Christodoulos, pp.566, 596; Machairas, 1162. 150; Prodromos, Testament of Neilos For The Monastery of St. John The Forerunner (Prodromos) on Mount Athos, Trans. Reinert, Stephen, BMFD 48, Washington 2000, p.1393; PADOver, Byzantine Libraries, p.323.

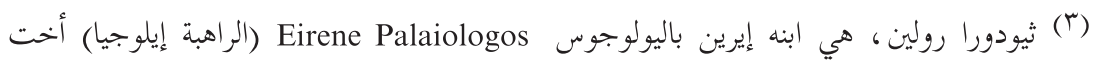

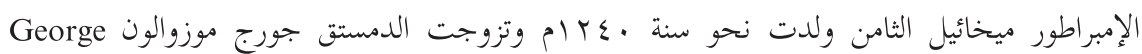
Mouzalan

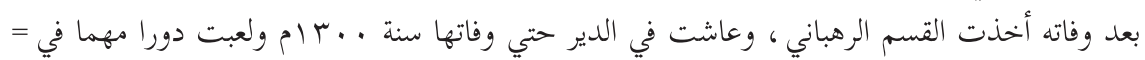


معها مكتبتها الخاصة لدير القديس أندروس (1) Andrews بالقسطنطينية ، وقد قامت بتجديده وتلقت فيه النذر الديرية، وقد احتوت مكتبتها على مؤلفات عديدة

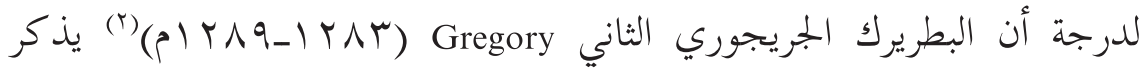

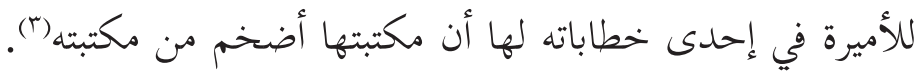
كما أن شراء الكتب لتزويد مكتبة الدير كانت ممارسة معروفة في الدولة

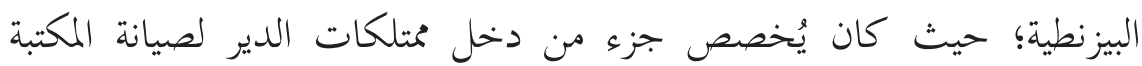

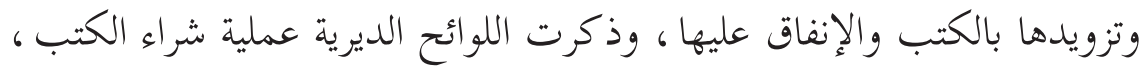
فيذكر خريستودولوس نفسه في لائحه ديره ، بأنه اشترى الكثير من الكتب من بن

Nicol, D.M., The Byzantine Family of . الحياة الثقافية والدينية للإمبراطورية = Kantakouzenos (Cantacuzenus) Ca. 1100 1460, Washington 1968, pp.16-17; ؛Fassoulakis, S., The Byzantine Family of Raoul-Ral (L) es, Athens 1973, p.26

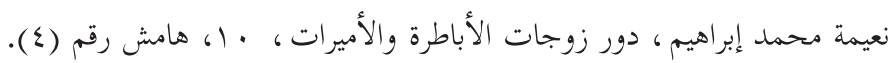

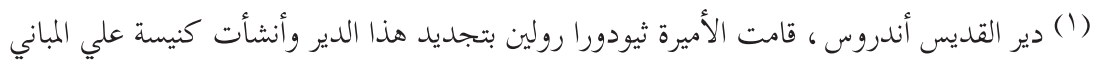

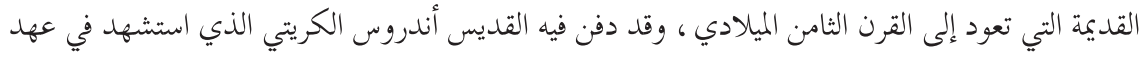
الإمبراطور قنسطنطين الخامس Constantine V

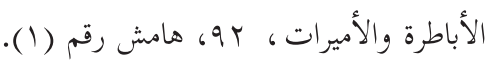

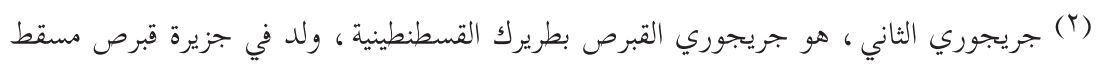

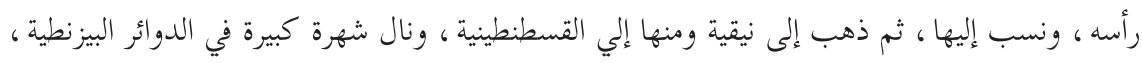

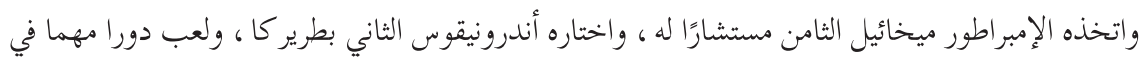

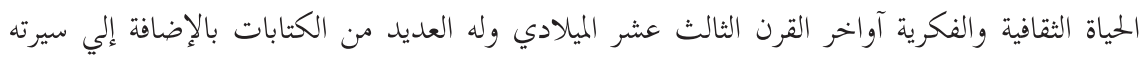
الذاتية. ولمزيد من التفاصيل عن دورة في الحياة الفكرية البيزنطية: PAPDAKIS, A., Crisis in Byzantium The Filioque Controversy in The Patriarchate of Gregory of Cyprus (12831289), New York 1983, pp.24-47; Constantinides, C.N., Higher Eudction in Byzantium in The Thirteenth and Early Fourteenth Centuries (1204 - ca 1310), Nicosia 1982 pp.32-6; ODB, 2, pp.876-7 نيكول ، معجم التراجم البيزنطية ، صr.

(3) Gregory OF Cyprus, Letters, ed. E. Eustratiades, E ph IV (1909), pp.116-19, 
أمواله الخاصة : (امعظم الكتب المن كورة آنفا اشتريتها بمجهودي وعلي نفقتي

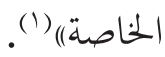

وتذ كر لائحة دير ميخائيل أطالياتيس Micheal Attaleiates التي تم الحصول عليها بالشراء ، ومنها عدة نسخ من الإنجيل و كتاب الفصول وسير القديسين وبعض الكتب المستخدمة في الطقوس الدينية لتلبية احتياجات

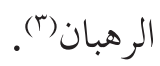

فضلًا عن ذلك ، فقد لعبت الهبات والمنح التي كان يقدمها الأفر اد للدير وقد كان من بينها الكتب دورا مهما في إمداد المكتبة الديرية ، سواء أكان هؤلاء الأفر اد أباطرة أو أمراء أو رجال دين أو حتى أفراد عاديين ، والتي قدمها بعضهم نتيجة لمرورهم بالدير وحسن ضيافتهم فيه ، أو طلبًا للخلاص وإرضاء للرب أو اعتر افًا بالفضل والجميل له ، 6 وتقدم التيبيكا العديد من الأمثلة علي ذلك ، ومثال ذلك ما قدمه الإمبر اطور ألكسيوس الأول كومنين Alexius I Komnenos (1) (1) باكوريانوس Pakourianos(๕) ، ومنها نسخة من الإنجيل مكتوبة باللغة اليونانية

V (1910) pp.450-2; Nicol, D.M., The Byzantine Lady Ten Portraits 1250-1500, Cambridge 1996, pp.40, 41, 43.

(1) Christodoulos, p 599.

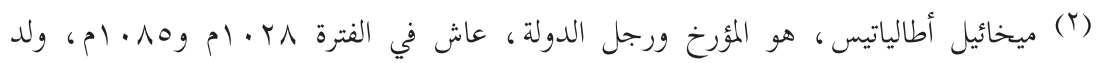

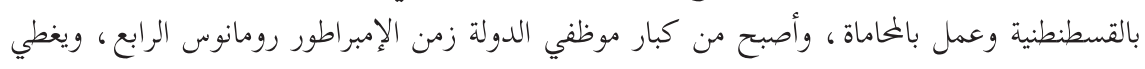

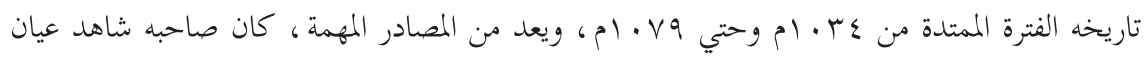

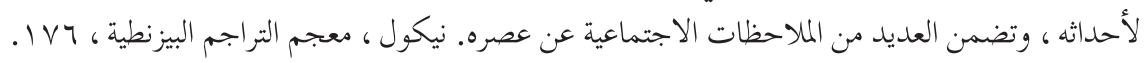

(3) Attaleiates, Rule of Micheal Attaleiates For his Almshouse in Rhaidestos and For The monastery of Christ Panoiktirmon in Constantinopl, Trans. Talbot, Alice-Mary, BMFD, 19 Washington 2000, p326.

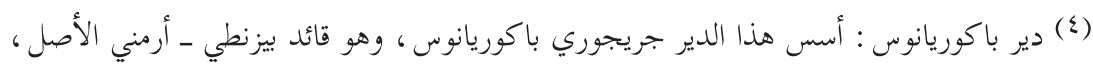

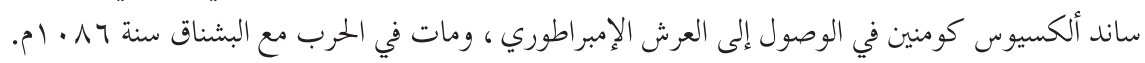

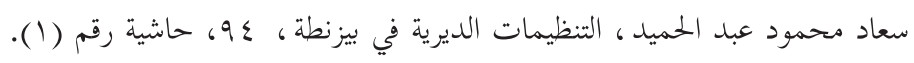


ومرصعة بالأحجار المتنوعة واللؤلؤ المطلي بالمينا بتكلفة عالية(1) ، وقدمت الأميرة

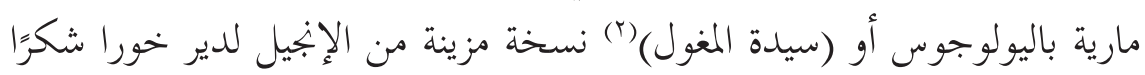

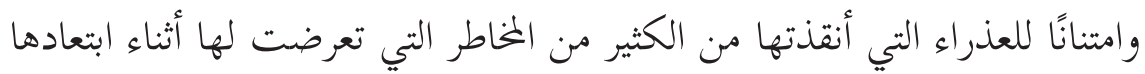
عن أسرتها في القسطنطينية وزواجها وإقامتها في بلاد المغول (؟). وتذكر لائحة دير أطالياتيس العديد من الكتب التى قدمها عدد من الموظفين والرهبان للدير ، فقدم الراهب يوحنا ، وهو سكرتير رئيس الدير نسخة الديس

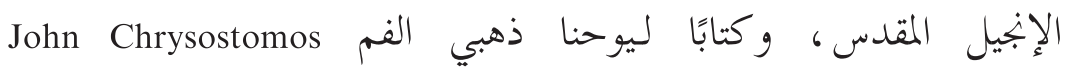

(1) Pakourianos, Typikon, of Gregory Pakourianos For The Monastery of The Mother For The Monastery of The Mother of God Petritzonitissa in Backovo, Trans. Jordan, Robert BMFD, 23, Washington 2000, p 526.

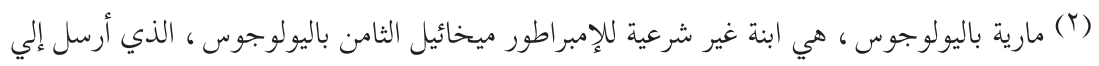

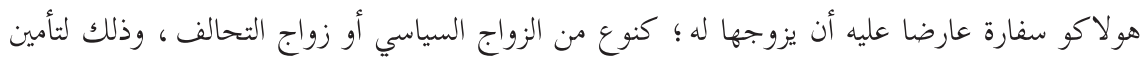

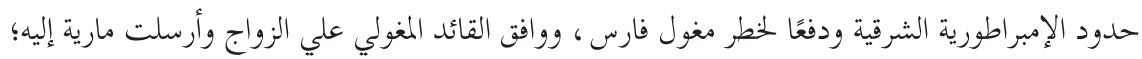

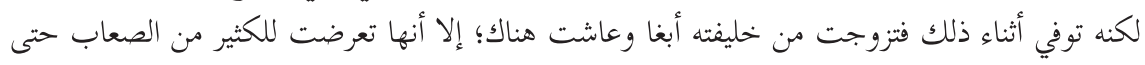

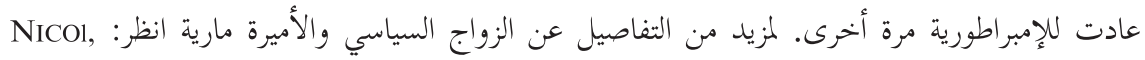
D.M., «Mixed Marriages in Byzantium in The Thirteenth Century» in: Byzantium : Its Ecclesiastical History and Relations with The Western World, London 1972, pp.160-8; IzEDDIN, M., «Notes sur les Mariages Princiers en Orient ou Moyen Age» JA, cclvi I

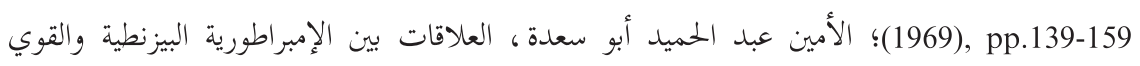

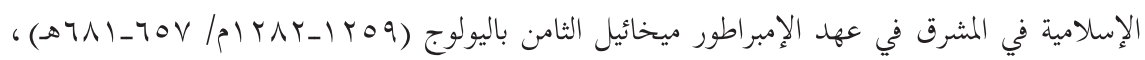

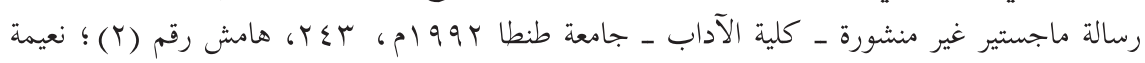

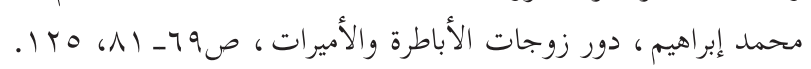

(3) TALBOT, A-M., «Building Activity in Costantinople under Andronikos: The Role of Women Patrons in The Construction and Restoration of Monsteries» in: Byzantine Constantinople Monuments Topography and Everday Life, ed. Necipoglu, N., Brill 2001, p.335; Teteriatinko, N., «The Dedication of The Chora Monstery in the time of Andronikos Palaiologos», B xvi (1996), pp.195-6 نعيمة محمد إبراهيم، دواط الإن،

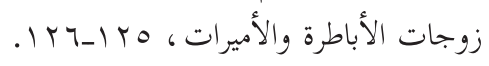




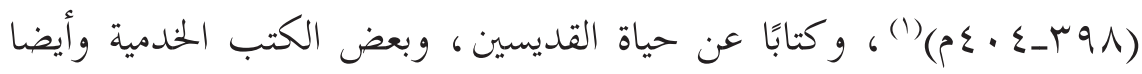

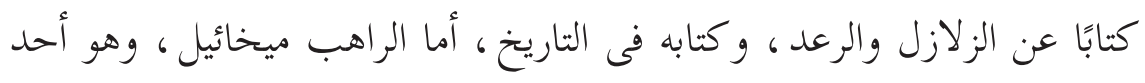

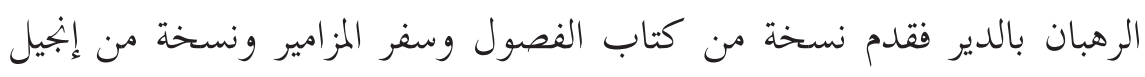

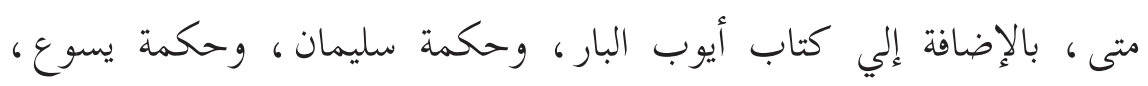

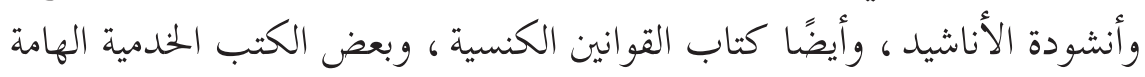

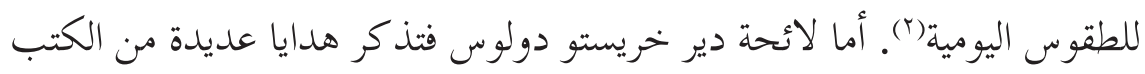
قدمها أشخاص من جزر رودس ، خيوس ، كريت لمكتبة الدير في القرن الثاني

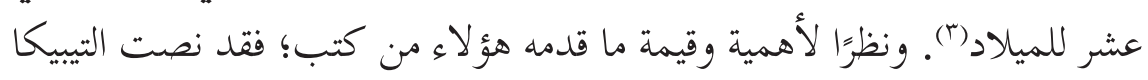

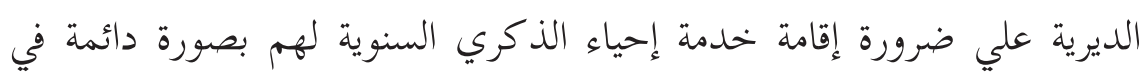
الطقوس اليومية(乡) كذلك كان تبادل الكتب والاستعارة بين رؤساء الأديرة عاملاً

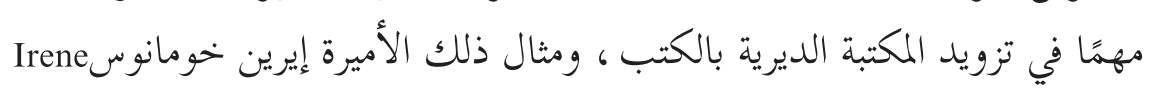
Choumnos ${ }^{(0)}$

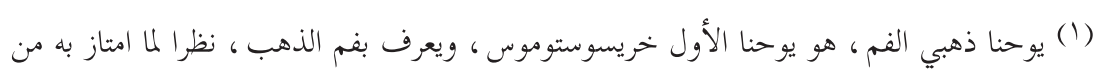

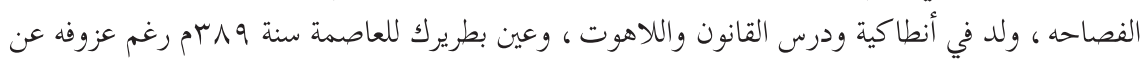

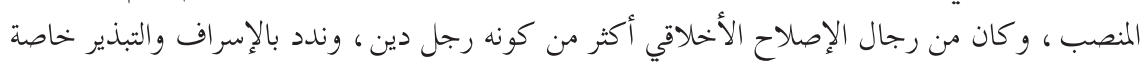

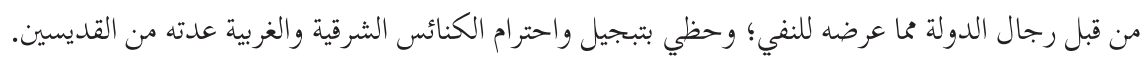

(2) Attaleiates, p357. . نيكول ، معجم التراجم البيزنطية ، .7.

(3) Christodoulos, p.357; Padover, Byzantine Libraries, p 323; Wilson, Libraries of The World, p.70.

(4) Attaleiates, p.358.

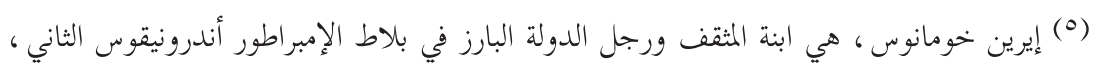

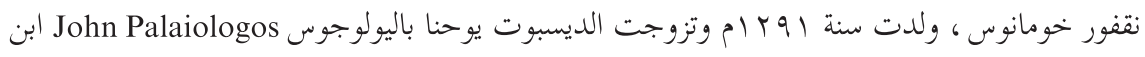

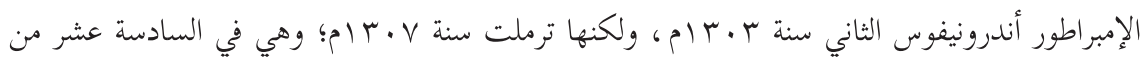

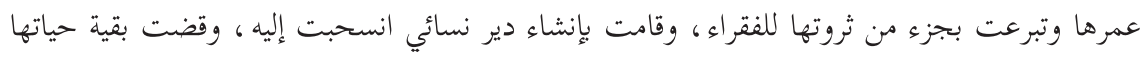

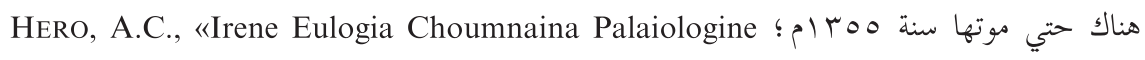


الأميرة ، وقد طلب منها مرشدها الروحي أو معلمها أن ترسل له قائمة بالكتب

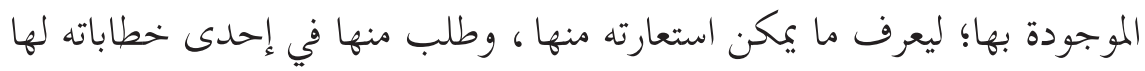

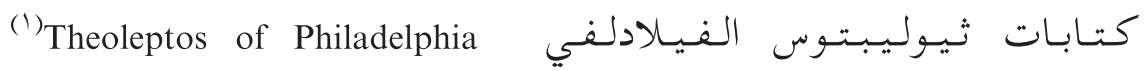

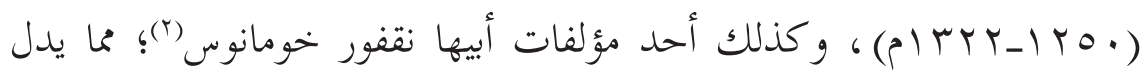
علي وجودهما في مكتبة ديرها ، وطلبت هي في أحد خطاباتها له مؤلفه عن احن

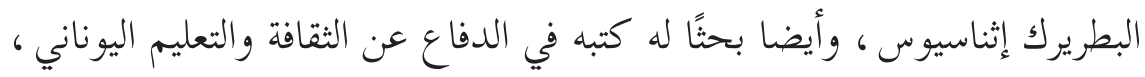

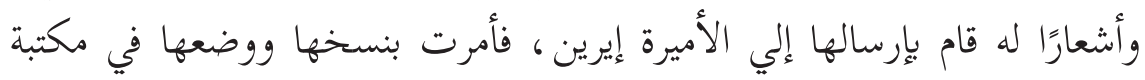

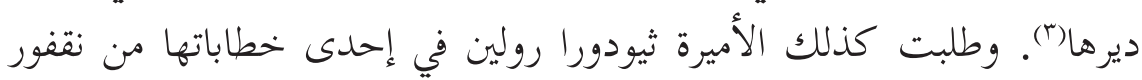

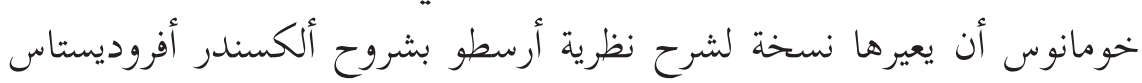

Abbess of The Convent of Philanthropos Soter in Constantinople» BF ix (1985),

pp.432-3; $O D B$, I, pp.432-3.

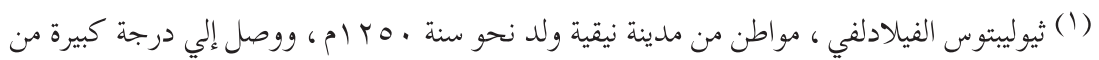

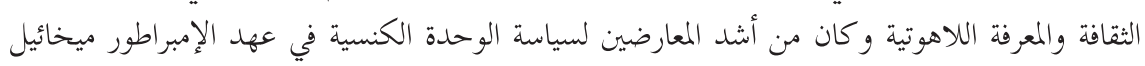

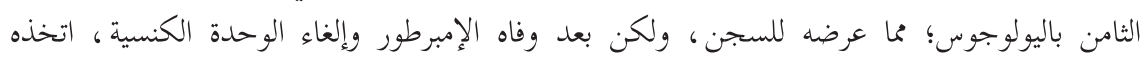

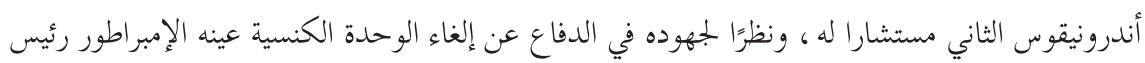

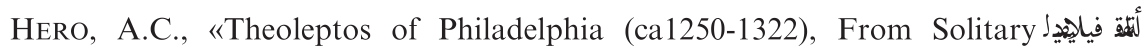
to Activist» in: Twilight of Byzantium : Aspects of Cultural and Religious History in The late Byzantine Empire, Princeton 1989, pp.27-39.

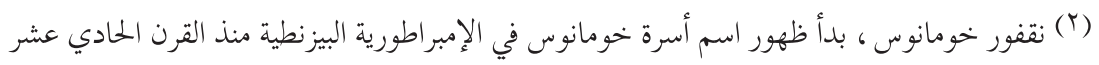

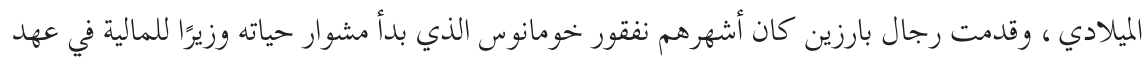

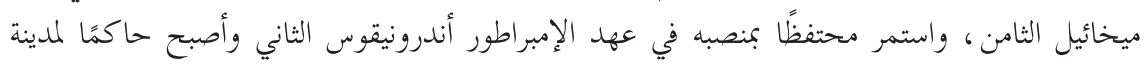

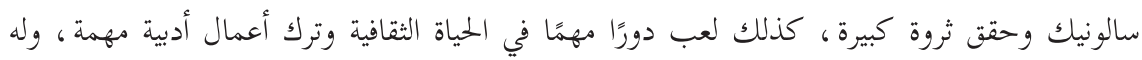

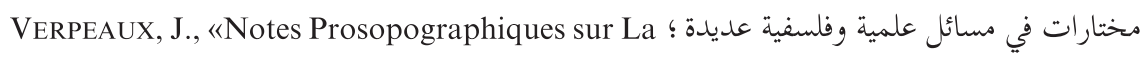

Famille Choumnos» BS 20 (1959) pp.252-266.

(3) Irene-Eulogia, A woman's Quest For Spiritual Guidance: The Correspondence of Princess Irene-Eulogia Choumnaina Palaiologina, Trans. Hero, A.C., Brookline Mass 1926, Letters. No.2, 4, 7, 12. 
Alexander Aphroditsias

$$
\text { ووضعته في مكتبة ديرها('). }
$$

كذلك كان يخصص جزء من دخل متلكات الدير لصيانة المكتبة وتزويدها

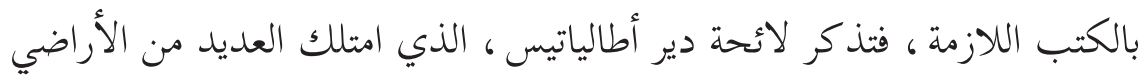

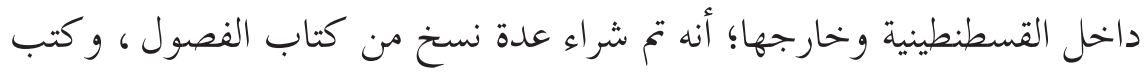

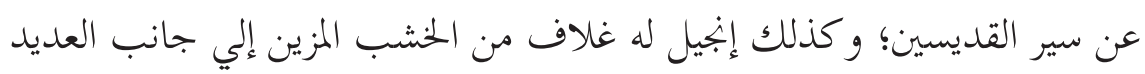
من الكتب الأخري لتلبية احتياجات الرهبان (r).

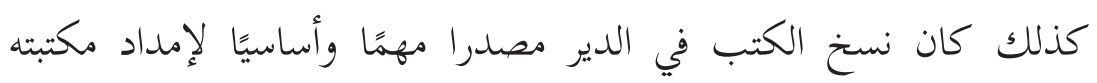

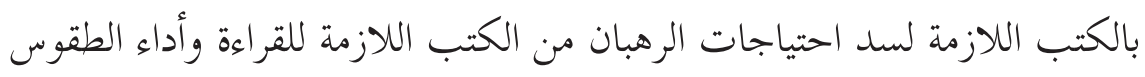

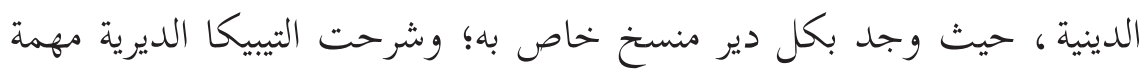

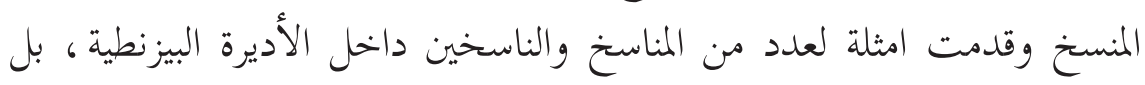

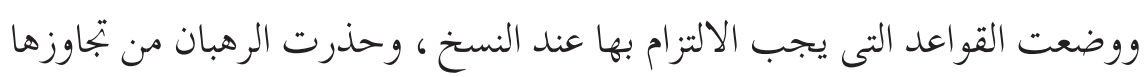
وحددت العقوبات لمن يخالف ذلك(r).

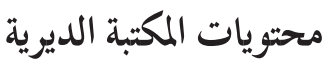

إذا تحدثنا عن محتويات المكتبة الديرية فيمكن القول بأن هذه المكتبات قد احتوت علي العديد من الكتب الدينية والدنيوية التي يمكن تقسيمها ، محت كما هو

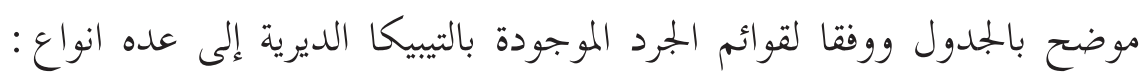
كتب صلوات وطقوس أو كتب خدمية ، وقد اشتملت علي الأناجيل المقدسة وتفسيرها وكتاب الفصول ، الذي يحتوي علي عده فصول من التوراة تستخدم

(1) Choumnos, N., Letters, ed. Leone, p.m.1., EEBS, XXXIX-XI (1972-3), p.90.

(2) Attaleiates, pp.16-326.

(3) Stoudios, ch3, p.632; Christodoulos, p.599. 
في الصلاة ، والسنسكار Synaxarion، وهو تقويم سنوى لأيام أعياد القديسين والأعياد العظمي في الكنيسة، ويحتوي علي القراءات التي تتلي والصلوات والخدمات التي تؤدي في كل عيد علي حده ، إلي جانب كتاب أعمال الرسل وكتب المدائح والخطب الدينية والأدعية والترنيمات التي لم يخل فيل منها أي دئي دير؛ وذلك بسبب اعتماد الرهبان عليها في تأدية طقوسهم اليومية في الأيام العادية وأيام الصوم ، وفي الأعياد والاحتفالات وذكري القديسين. وفيما يأتي مثالين لحمتويات المكتبة الديرية كما ورد باللوائح الديرية.

(نوذجان من قوائم جرد المكتبات الديرية)

\begin{tabular}{|c|c|c|}
\hline $\begin{array}{c}\text { أطانياتيس } \\
\text { Attaleiates }\end{array}$ & $\begin{array}{c}\text { نيوس دمائيس } \\
\text { Neilos Damilas }\end{array}$ & أنواع \\
\hline \multirow{2}{*}{ الأثاجيل المقدسة- ونسخة أخرى بشرح } & الأناجيل المقدسة & \multirow{11}{*}{ و الطققوس ات } \\
\hline & \multirow[t]{2}{*}{ التعهد الجنيد } & \\
\hline كتاب مختصر للإنجيل & & \\
\hline أعمال الزرسل & Apostolos (كتاب أعمال الزرسل) & \\
\hline المز امير له نسخ عليدة - سفر الزؤيا & 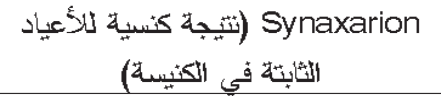 & \\
\hline Oktoechos & Oktoechos (كتاب طقوس يحتوى & \\
\hline \multirow[t]{2}{*}{ 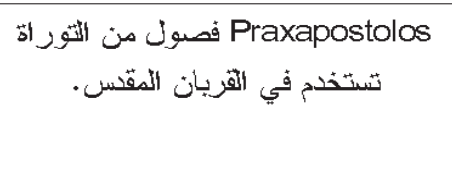 } & على الثزئيمات الثتي تثلى في القربان & \\
\hline & كتاب خدمة للعشاء الترباتي & \\
\hline \multirow[t]{2}{*}{ 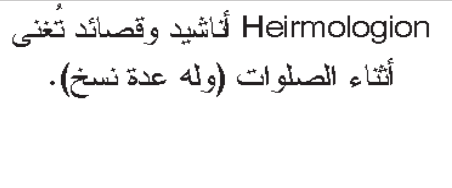 } & لثز الثيل الخمسين يوم لكوسم العنصرة) & \\
\hline & Euchologion (كثاب طقوسي & \\
\hline 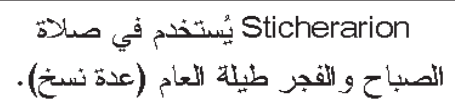 & 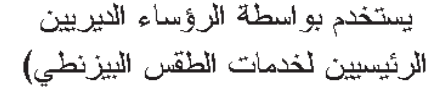 & \\
\hline
\end{tabular}




\begin{tabular}{|c|c|c|}
\hline الكثاب الشهري!Menion & \multirow{2}{*}{ 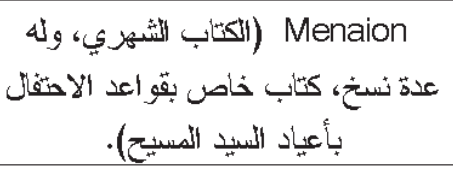 } & \\
\hline \multirow[t]{2}{*}{ شرح يوحثا الذهبي على إنجيل مثنى } & & \\
\hline & طقنسان ليوحنا الأذهي & \\
\hline كتاب القصول & $\begin{array}{c}\text { Gospel-Lectionary } \\
\text { (كثب القصول) }\end{array}$ & \\
\hline عظاثت بيوحثا القم الذهبي & الكتباب الثلثي لثيوحثا القم الذهبي & \multirow{5}{*}{ 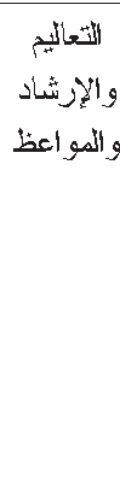 } \\
\hline أمثلى وحكم سليمان & 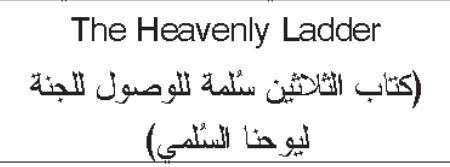 & \\
\hline الأيام الأستة في تثنيز الخليقة لنيوحنا القخر & \multirow[t]{3}{*}{ 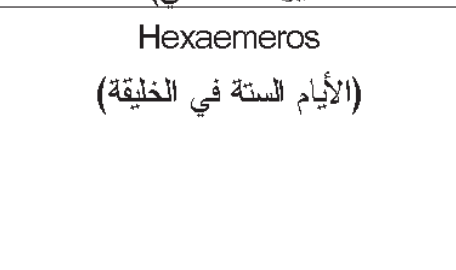 } & \\
\hline كثاب النستة أبيام للقيس بإسيل & & \\
\hline حكمة يسوع المسيتح مع الثرح و التعليث & & \\
\hline 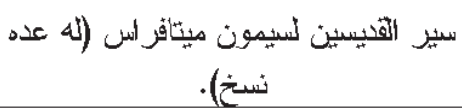 & سيز القيسيني، لسيمون ميثاثز اس & \multirow[t]{5}{*}{ الألصصن } \\
\hline 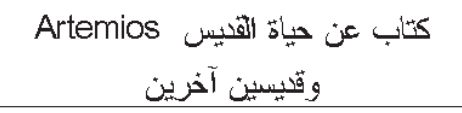 & Mother of God كتب عن العثر اء؛ & \\
\hline كتب عن القيس ديوثيسيس & (كتب الثبوء \&ت) Propheteia & \\
\hline عشرة كثب لنيمون ميتاقز اس & كتاب عن سيز القيسين & \\
\hline كتاب أييوب البار & سفر ئيوب الثاز & \\
\hline \multirow[t]{3}{*}{ كتب عثائدي اللقيس بأسيل } & 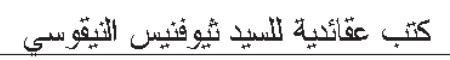 & \multirow{3}{*}{ الكعثائئية } \\
\hline & 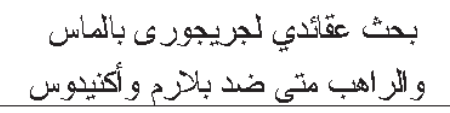 & \\
\hline & أقو الن بيوحثا القم الذهبي & \\
\hline \multirow[t]{3}{*}{ كتاب في الالاهوت لئيوحنا الخمشقي } & كتاب لجزيجوري اللاهوتي & \multirow{3}{*}{ 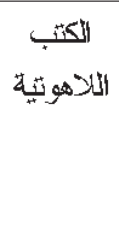 } \\
\hline & أبحاث لمكسيموس التر اهب و أخرى & \\
\hline & الأعمال النانهوتية للقنيس مكسيموس & \\
\hline
\end{tabular}




\begin{tabular}{|c|c|c|}
\hline القو اثين الكنسية & \multirow{2}{*}{ 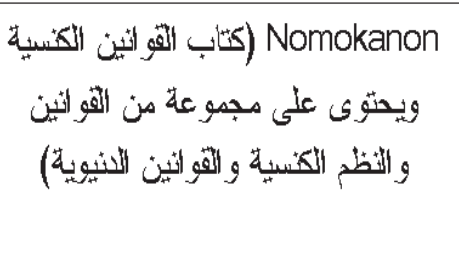 } & \multirow{2}{*}{ 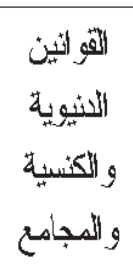 } \\
\hline كتب عن البطرزكة & & \\
\hline 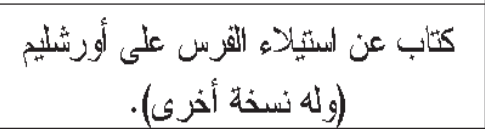 & & \multirow[t]{4}{*}{ الكتبثية } \\
\hline كتب تناريخي للمؤسس أثنائاتس & & \\
\hline كتب الملوك (وله عدة نسخ). & & \\
\hline حولية عزر الية & & \\
\hline كتاب في اللغثة والأسلوب & 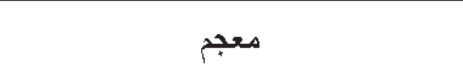 & \multirow{7}{*}{ وتئب } \\
\hline كتاب للقليس يو حنا الثنازيزى & \multirow[t]{2}{*}{ مجمو عة كتب أنبية للقيس أنشتانييوس } & \\
\hline كتاب الثماثيليل & & \\
\hline كتاب ددح للقيسين و البطاركة والأباطرة & كثاب بو اسطة في تئيس & \\
\hline & \multirow{3}{*}{ مجموعة كثب عن الحب و القلسفة } & \\
\hline كثاب ثليودور ستوبيوس & & \\
\hline كتب أغثنية الأغانتى & & \\
\hline 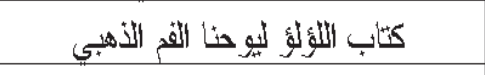 & \multirow[t]{2}{*}{ كثب للقيب نروسييوس Dorotheos } & \\
\hline كثاب في المدح & & \\
\hline كتب عن الزلازل و الز عد & & الظظ اهز \\
\hline كتاباتث نسكية للقليس بأسيل & \multirow[t]{3}{*}{ الثيكون الخاص بالثير } & \multirow{3}{*}{ والثليزية } \\
\hline كتابات مخترة من الأعمال الثشكية & & \\
\hline تثليماتث عن القو اعد و الحياة الثنكية & & \\
\hline
\end{tabular}


أما كتب القصص الديني التي تناولت سيرة حياة القديسين والقديسات؛ فقد

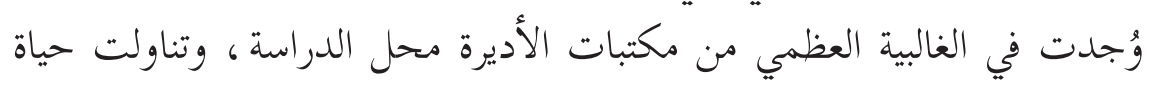
وأخلاق هؤلاء القديسين والمشاق التي واجهتهم و كيف تغلبوا عليها ومعجزاتهم ،

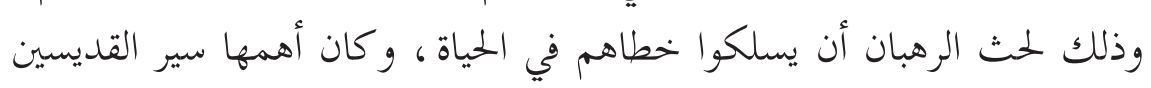

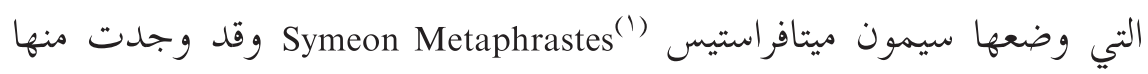

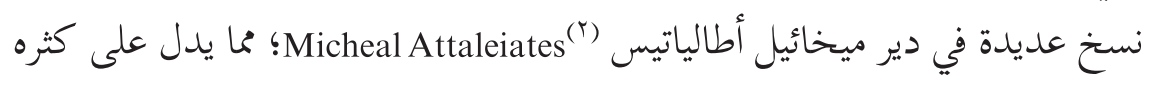

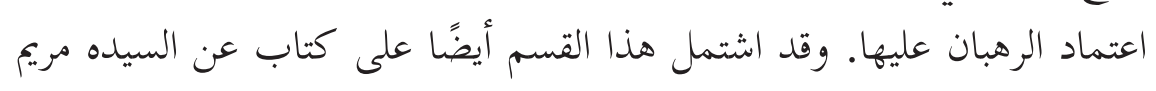

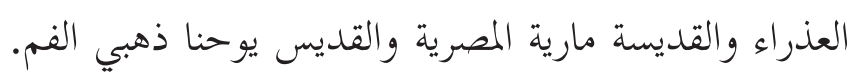

يليها الكتب العقائدية واللاهوتية التي تناولت بالشرح جوانب العقيدة المسيحية والتصدي للهرطقات؛ ومنها كتاب عن الزهد للقديس باسيل العظيم وعدة مؤلفات ليوحنا الدمشقي و(r) وغيرها.

(1) سيمون ميتافراستيس ، كاتب وموظف كبير في نهاية القرن العاشر توفي سنة . .. (1م، و وكانت

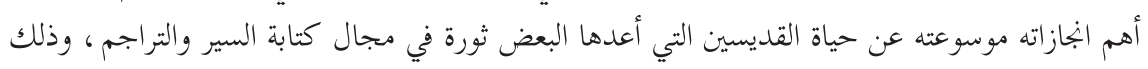

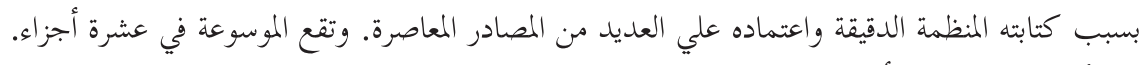

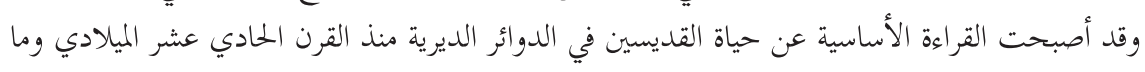

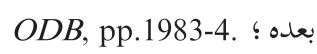

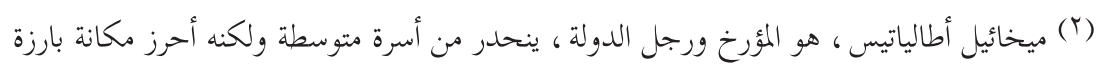

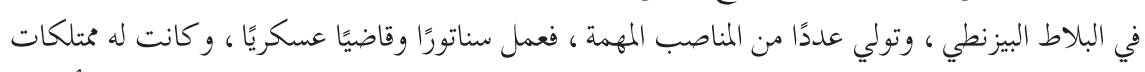

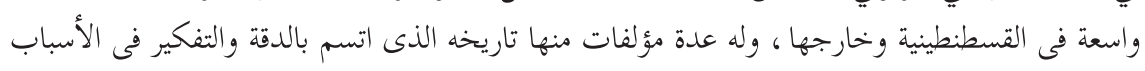

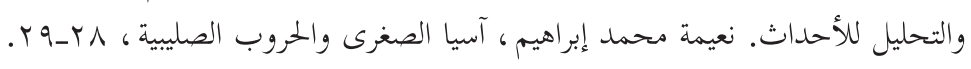

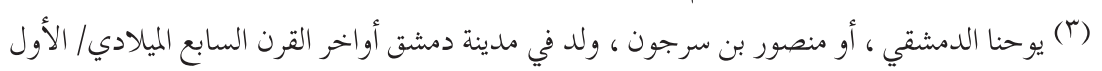

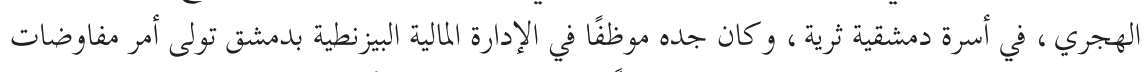

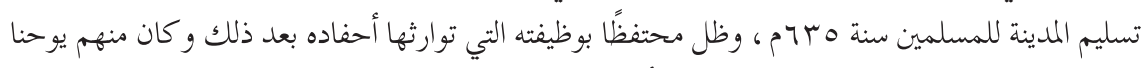

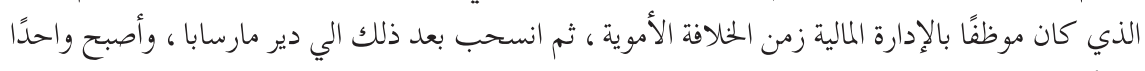

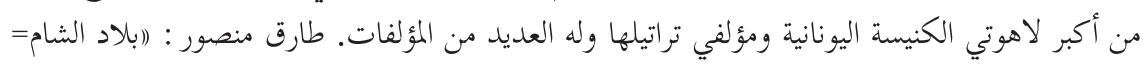


أما كتب القوانين الكنسية وأعمال البطاركة ، فقد حظيت باهتمام مؤسسي

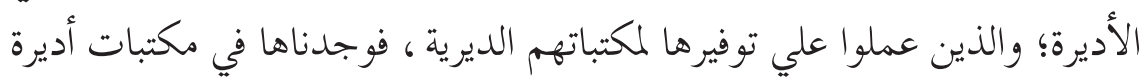

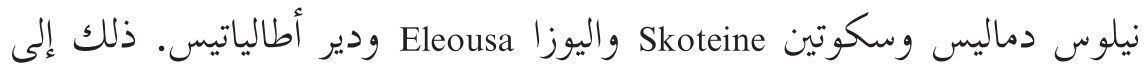

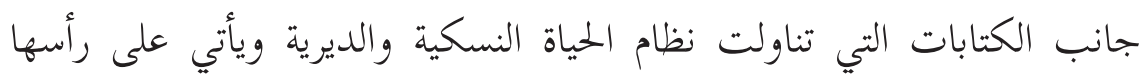

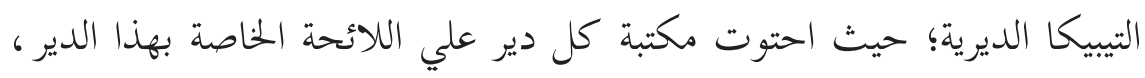
وحث مؤسسو الأديرة علي قراءتها باستمرار بل ونصت بعضيكا على على قراءة الرهبان

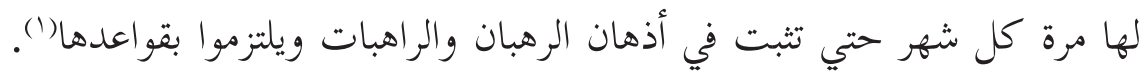

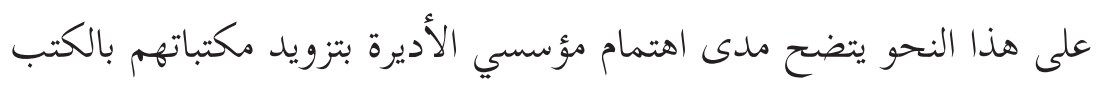

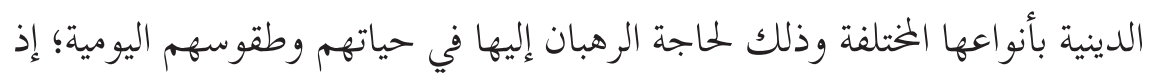

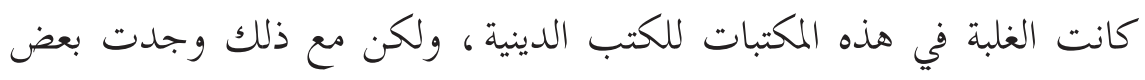

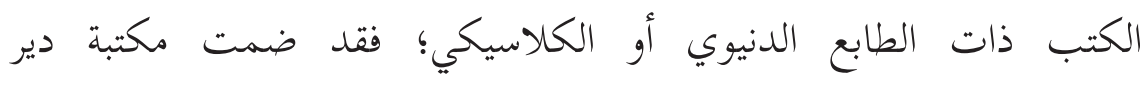
خريستودولوس كتبًا دينية وغير دينية؛ إذ وجدت فيها مجموعة تحتوي علي

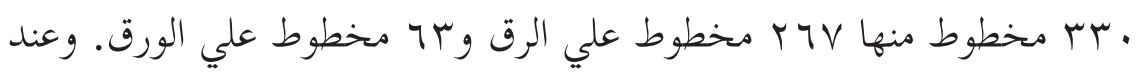

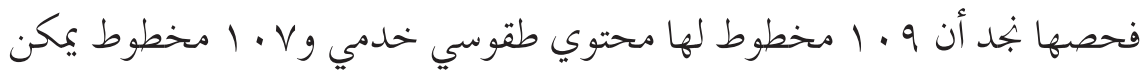

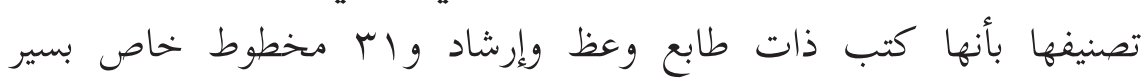

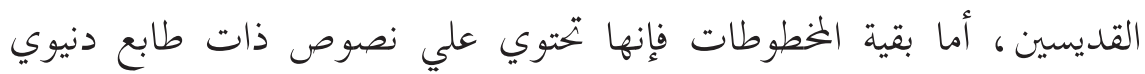

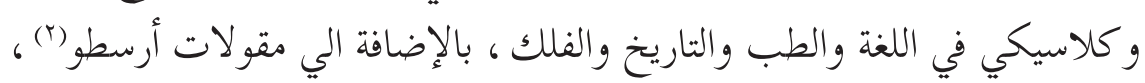

=وحوار الأديان في القرن الثامن الميلادي ـ رسالة عمر بن عبد العزيز إلي ليو الإيسوري ورد الأخير عليها

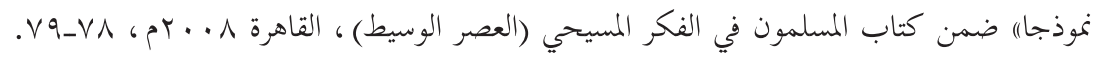

(1) LIPS, 432; Charsianeites, pp.1660-1661; KeCharitomene, p.698; MAHAiras, p.1165; BeBAia ElPIS, 1556-1557.

(2) DieHL, Ch. «Le Trésor et La bibliothéque de patmos au commencement du 13e siècle» BZ I (1892), pp.498-501; padover, Byzantine libraries, pp.323-4; STAIKos, TheHistory of The Library, p.308. 
و كذلك وجد في مكتبة دير أطالياتيس كتاب عن الزلازل والرعد ، فقد كان أمرًا

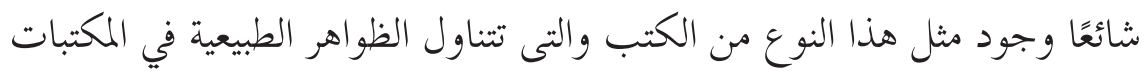

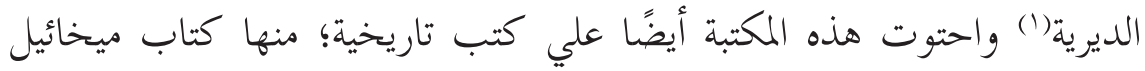

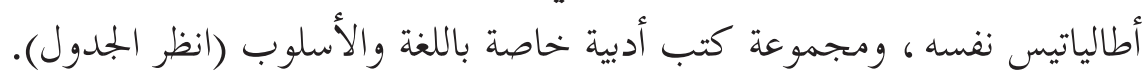

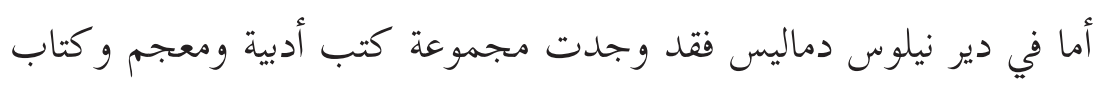

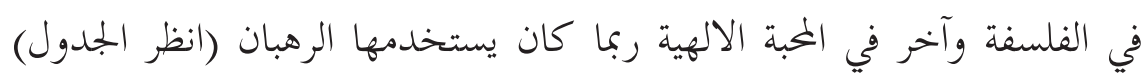

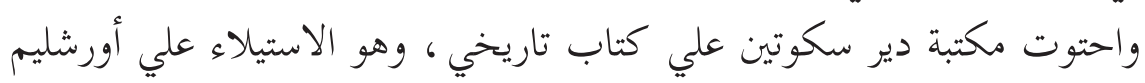

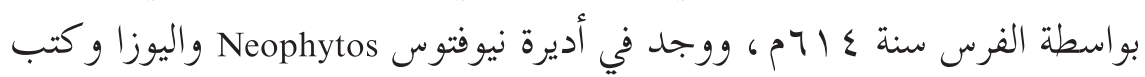

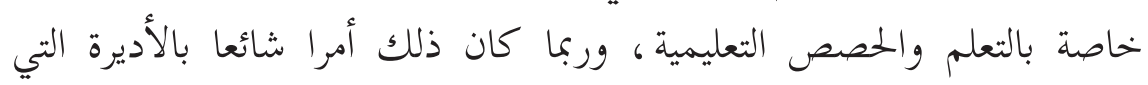
وجدت بها مدارس.

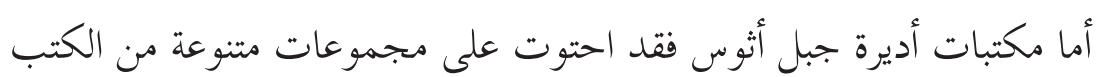

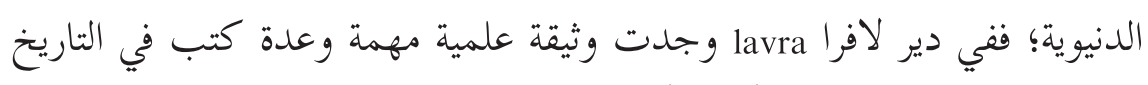

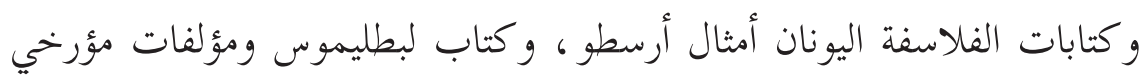

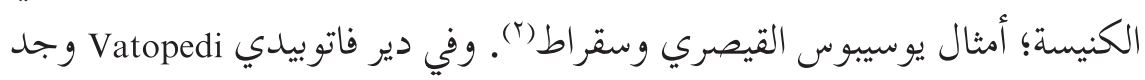

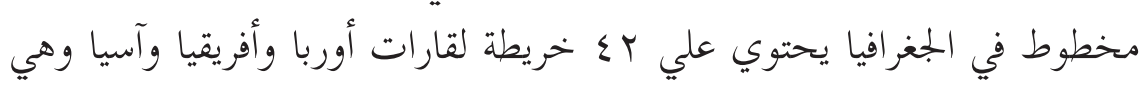

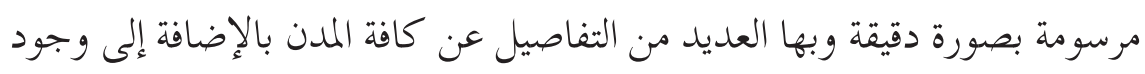

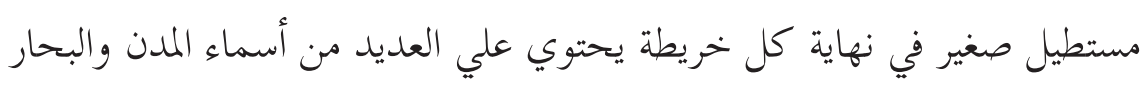

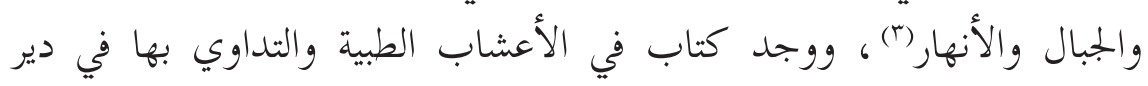

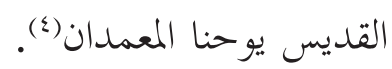

(1) WiLson, Libraries of The Byzantine World, p.64.

(2) WiLson, Libraries of The Byzantine World, p62.

(3) Staikos, The History of The Library, p.256.

(4) WILson, Libraries of The Byzantine World, p.64. 


\section{نظام الاستعارة داخل المكتبات الديرية}

لم تمدنا التيبيكا الديرية بمعلومات عن نظام الاستعارة الخارجية ، فالمكتبات

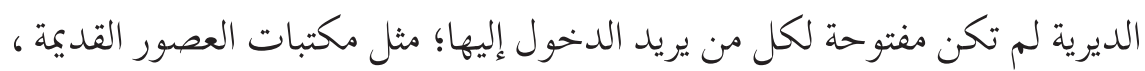

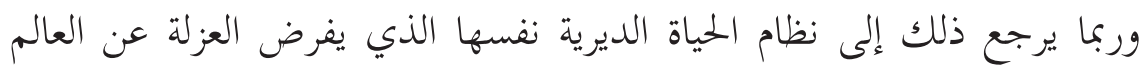

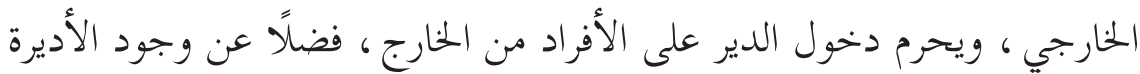

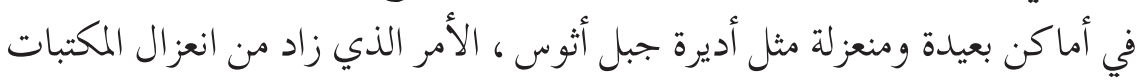

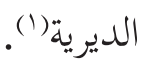

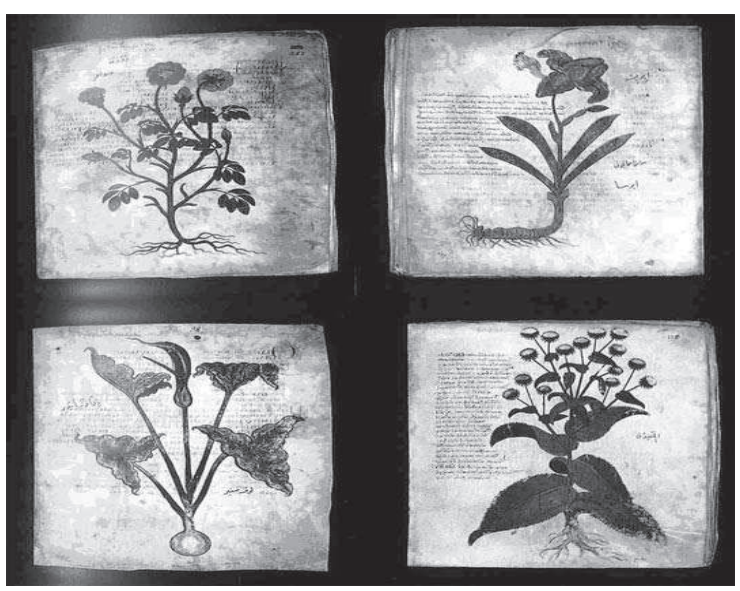

شكل (ع) نماذج من الكتابات الطبية بالمكتبات الديرية

(1) كان الأمر مختلفًا في أديرة الغرب الأوربي؛ حيث كانت الكتب تعار إلى خارج الدير إلى رجال

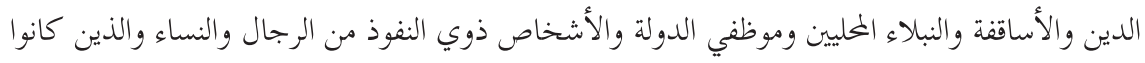

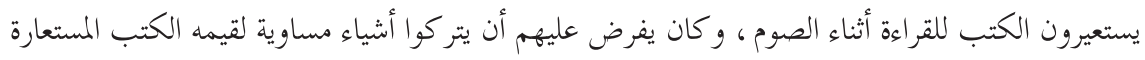

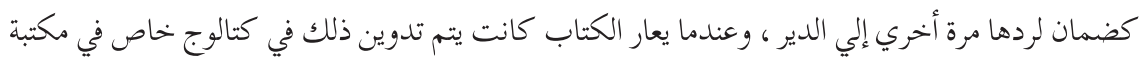

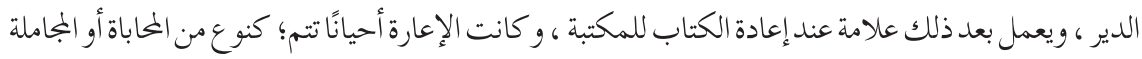

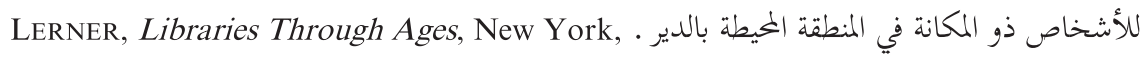


ولكن هذا لا ينفي وجود بعض الإشارات عن استعارة الكتب للخارج؛ فقى

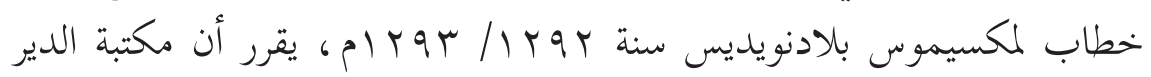
والذي كان به ، ربما دير خورا قد عانت من نقص وضياع الكتب ، وذلك ولك لأنها

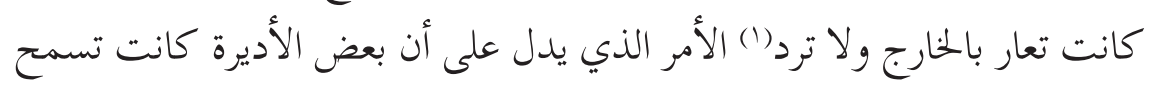

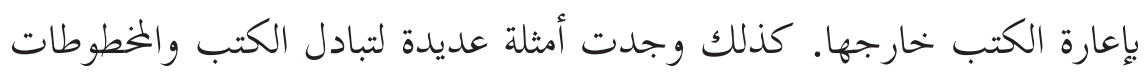

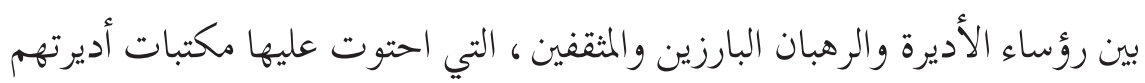

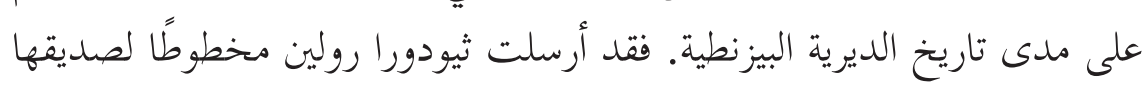
مكسيميوس بلانويديس من مكتبة ديرها ليصححة ويقارنه بالنسخة الموجودة

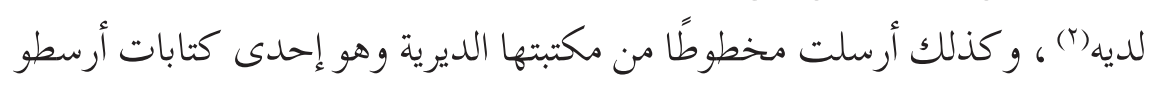

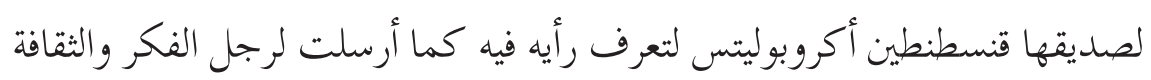

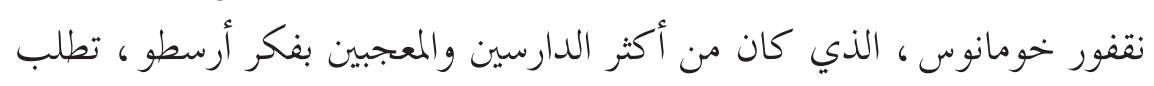

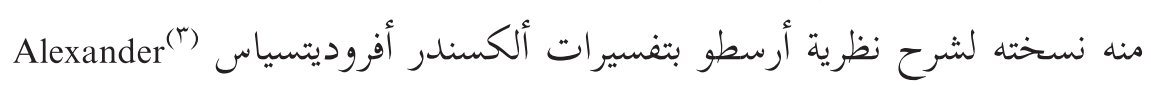

Aphroditsias.

وكذلك فإن الأميرة إيرين خومانوس استعارت من مرشدها الروحي الثاني(؛)

(1) Staikos, The History of The Library, p.426; Constantinides, Higher Education, pp.70-71.

(2) Nicol, Byzantine Lady, p.42; Constantinides, Higher Education in Byzantium, pp.77-78.

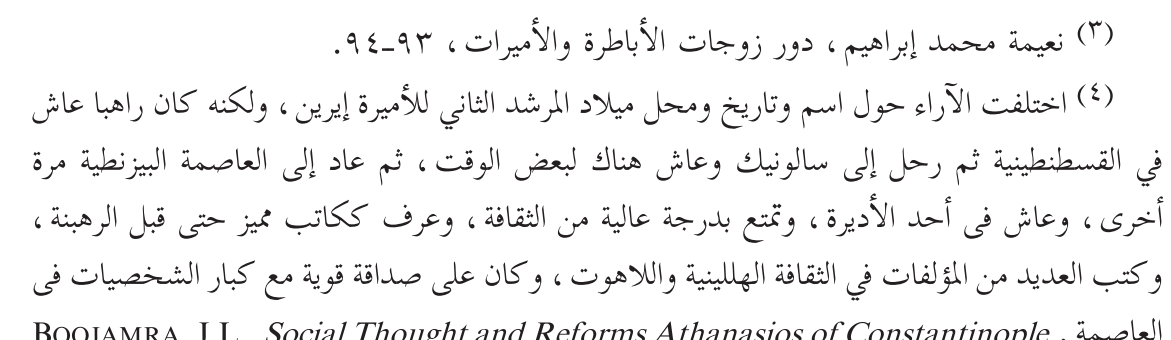

(1289-1293, 1303-1309), B lv (1985), pp.332-382. 
أعمال البطريرك أثناسيوس، و كتابات ألفها للدفاع عن التعليم الكلاسيكي ومجموعة أشعار له ، وفي المقابل أرسلت له الأسفار الخمسة للعهد القدئيم التي

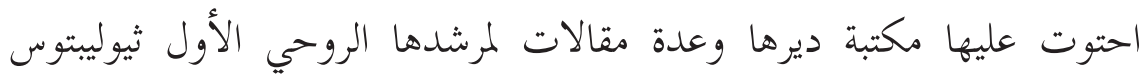

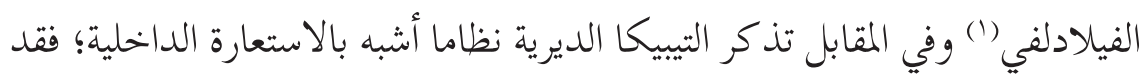

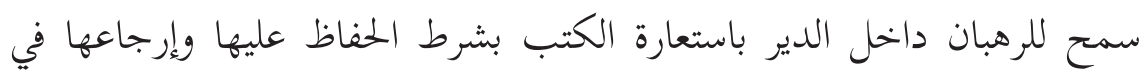

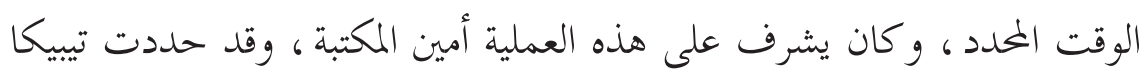

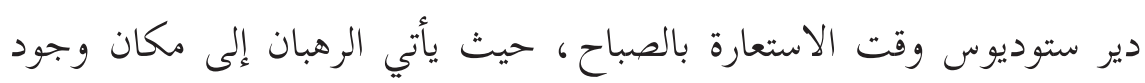

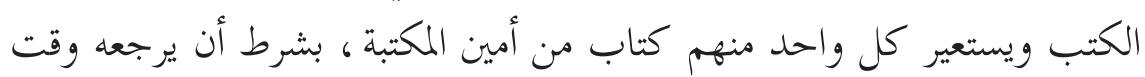

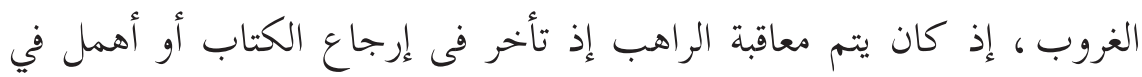

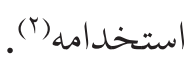

\section{أوجه الاستفادة من المكتبة داخل الدير}

لم تقتصر الخدمات التي قدمتها المكتبة الديرية علي تقديم الكتب اللازمة لتأدية

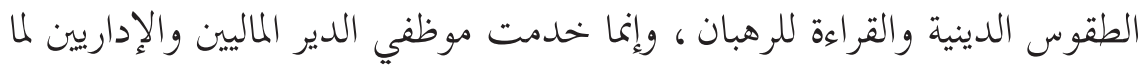

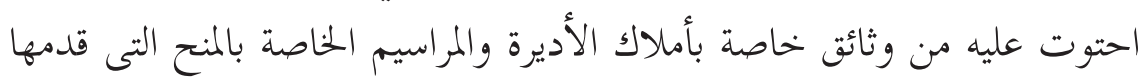

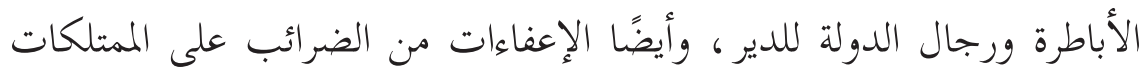
الديرية ، فضلًا عن القرارات الخاصة بعلاقة الدير بالسلطات المحلية فى منطقته.

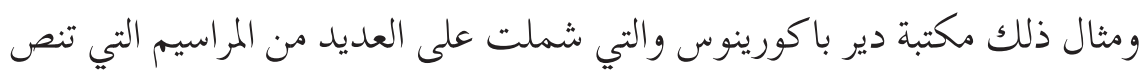

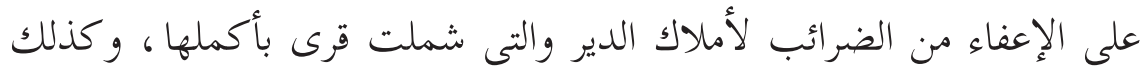
حمايتها من المصادرة وحرية تصرف مؤسس الدير في هذه الأملاك بما فيها حريته

(1) Corresponden Of Princess Irene, Letters. No.4. p.33, No.10 p.59, No.12, p.63.

(2) Stoudios, p.108. 


$$
\text { نعيمة محمد إبراهيم }
$$

في نقلها لأى شخص آخر ، و كذلك وجود وثائق تؤ كد استقلال الدير ضد أي تدخل (1)

فضلًا عن ذلك فقد أمدت المكتبة موظفي الدير بما يحتاجون إليه من نصوص

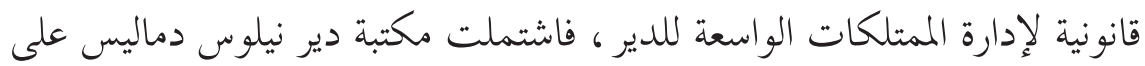

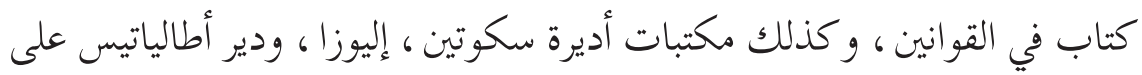

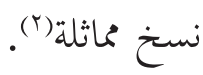
كذلك قدمت المكتبة الديرية المساعدة للدارسين في الدير ، لما احتوت عليه من كتب في مبادئ النحو والقواعد والإنشاء والأعمال الأدبية وأعمال الخطباء

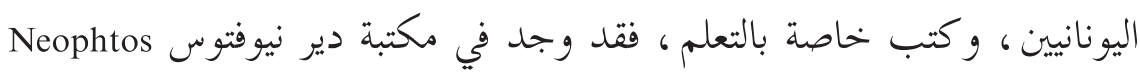

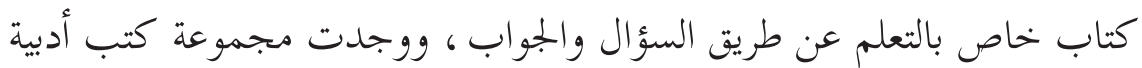
في دير نيلوس دماليس، وكتاب آخر يحتوي على مجموعة خطب في في دير ولير

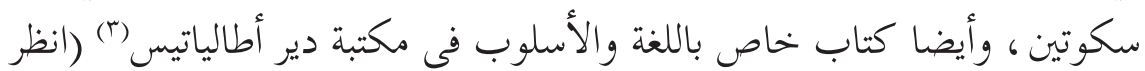

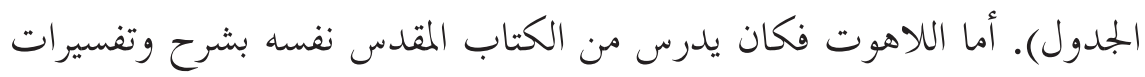
آباء الكنيسة ، فوجدت نسخة من الأنجيل بشروح وتعليقات يوحنا ذهبي الفم في

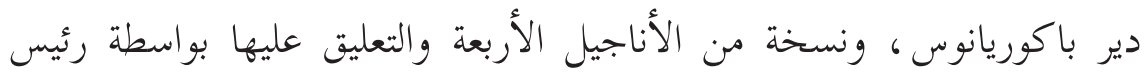

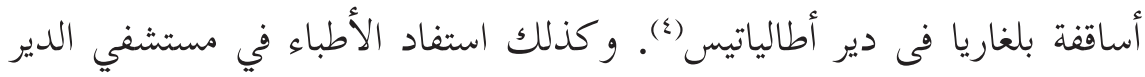
من المكتبة الديرية؛ لما احتوت عليه بعض المارياتيس المكتبات من الكتابات الطبية للأطباء

(1) PAKOURIANOS, pp.555-6.

(2) Neilos Damilas, p.1478; Skoteine [Boreine]: Testament of Maximos For The Monastery of The Mother of God at Skoteine near Philadelphia, Trans. Dennis, George, BMFD 35, Washington 2000, pp.1185-6; Eleousa Inv, pp.1672-1673; Attaleiates, p.359.

(3) Neophytos, p.1355; Neilos Damilas, p.1478; Skoteine, p.1185; AttALEIATES, p.359.

(4) Attaleiates, p.368. 
اليونانيين وكتب العقاقير والأعشاب وخصائصها واستخدامها في علاج بعض

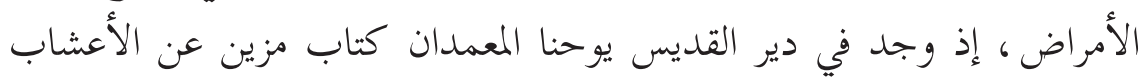
الطبية وفوائدها(')

\section{الدور الثقافي للمكتبة الديرية}

لقد مثلت الأديرة ومكتباتها مركزًا مهمًا من المراكز الثقافية والحضارية في

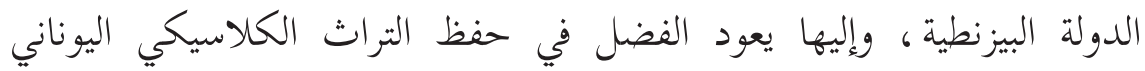

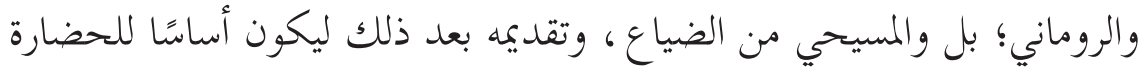

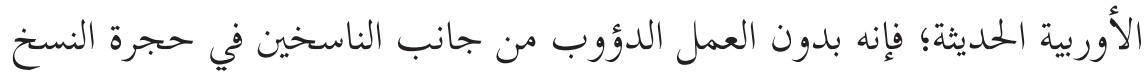

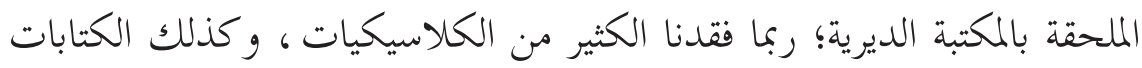

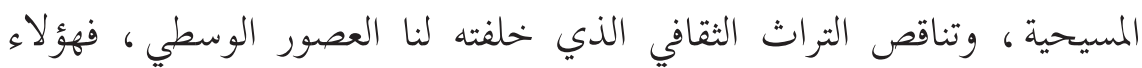

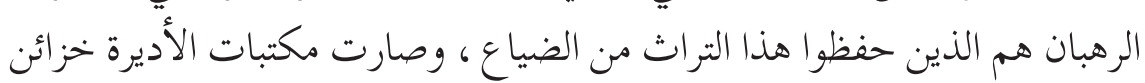
لحفظ الكتب والغخطوطات النادرة). وإذا كانت قد ظهرت موجة من الغضب وتمت محاربة دراسة الأدب والفلسفة اليونانية والعلوم والفلك من جانب بعض رجال الدين المسيحي الذين رأوا فيها

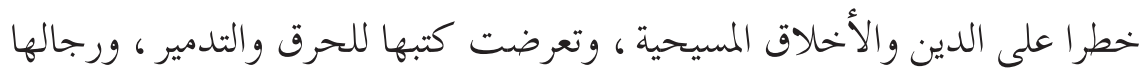

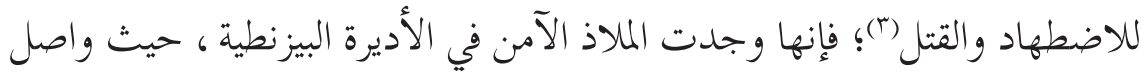
رجالها دراستهم هناك في هدوء، وشهدت هذة المجالات الهتمامًا كبيرًا أواخر

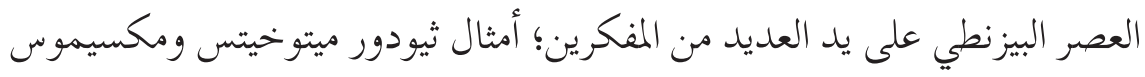

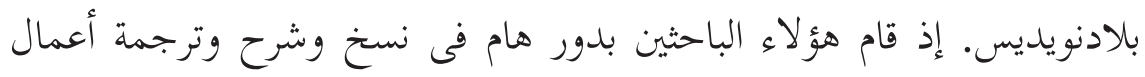

(1) LeRner, F., Libraries Through The Ages, p.34; Wilson, Libraries of The Byzantine World, p.65.

(2) PADOver, Byzantine Libraries, p.311.

(3) STAIKos, The History of The Library, pp.60-62. 
الفلاسفة والشعراء والجغرافيين القدامي ، وتركوا بعضها فى المكتبات الديرية؛ مثل

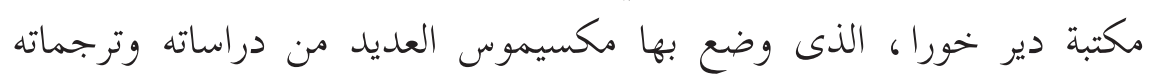

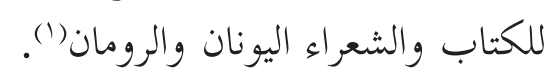
فضلًا عن ذلك فقد لعبت المكتبات الديرية دورًا مهمًا في التكوين الثقافي

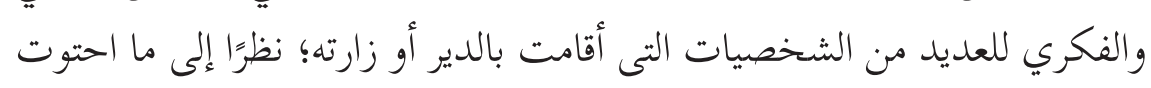

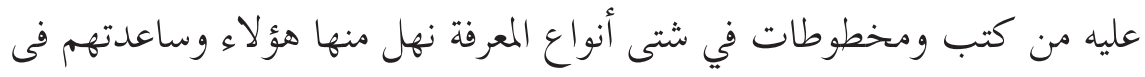

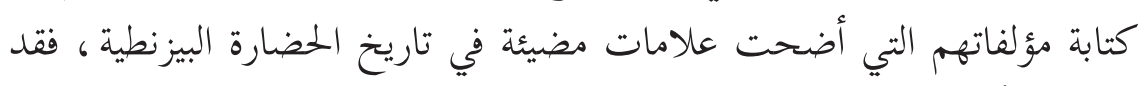

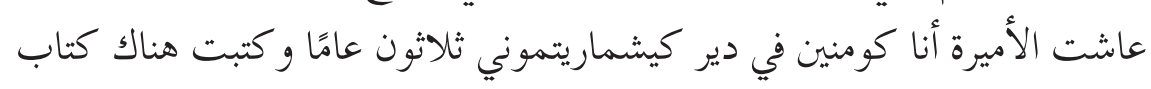

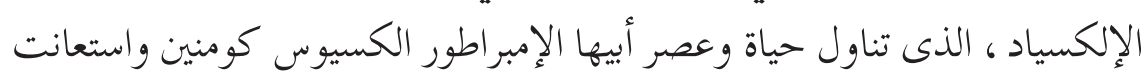

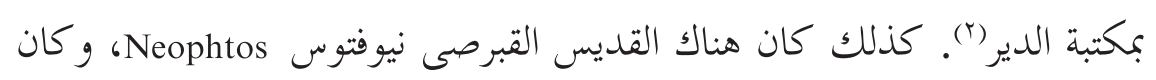
من أسرة فقيرة وغير متعلم ودخل الدير؛ حيث تلقى تعليمه الأول هناك وتعددت

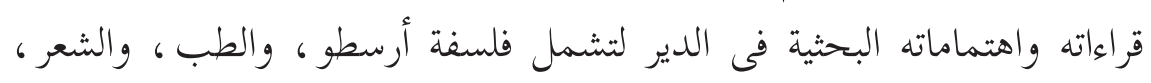

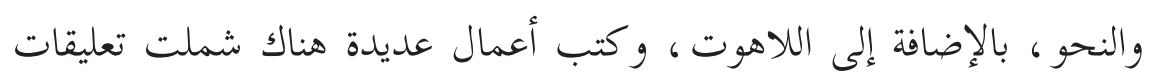

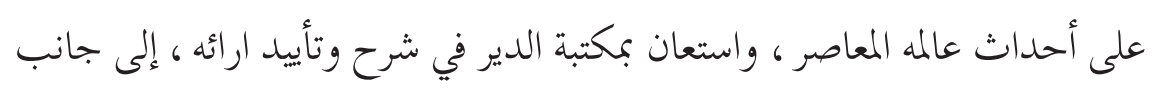
ما كان في حوزته من كتب كلاسيكية ودينية(r).

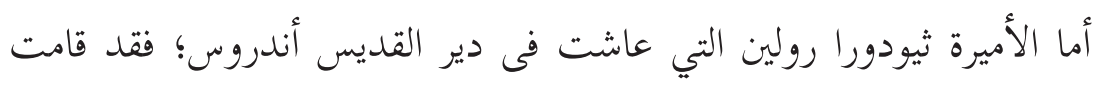
بتأليف سيرة القديسين ثيودور Theodore وثيوفانيس Theophanes اللذين فئ عرفا

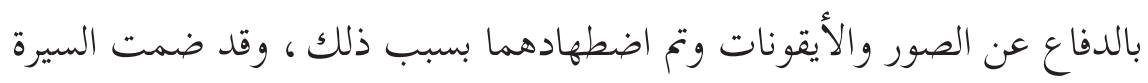

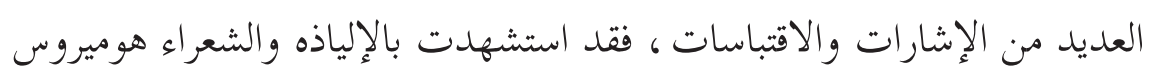

(1) Fryde, Palaeologan Renaissance, pp.228-246; StAikos, The History of The Library, p.427; Sevcenko, Theodore Metochites, pp.28/36-7.

(2) CAMERon, The Byzantines, p.137.

(3) CAmeron, The Byzantines, pp.138-139; ChARnis, The Monks as an element, p.81. 
وأيسخلوس وهسيسوديس وغيرهم ، إلى جانب الفلاسفة مثل أفلاطون ، الأمر

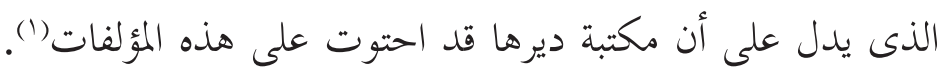
و كان هناك راهب آخر يدعي أنطيوخوس Antiochus قد عاش بدير مار سابا

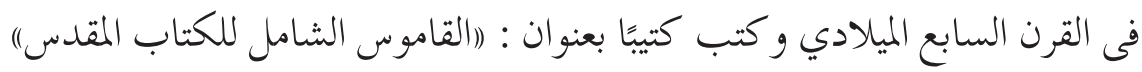
كان له قيمة كبيرة بسبب ما احتوى عليه من بيانات ومعلومات ، و وكذلك التوثيق

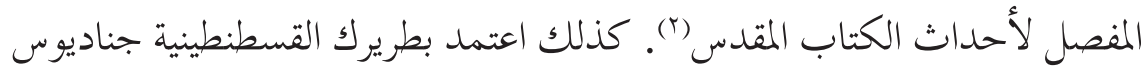
سكولاريوس Gennadios Scholarios على مكتبة دير بردورموس في كتابة أعماله

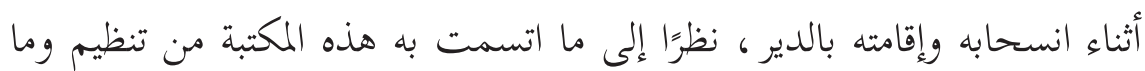

$$
\text { احتوت عليه من مخطوطات و كتب مهمة (r). }
$$

ووفرت أيضًا بعض هذه الأديرة ملاذا آمنا لبعض الشخصيات لكتابة مؤلفاتهم

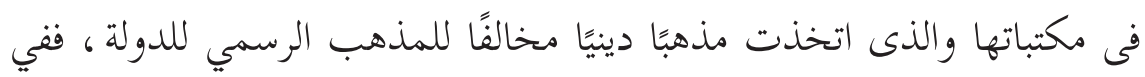

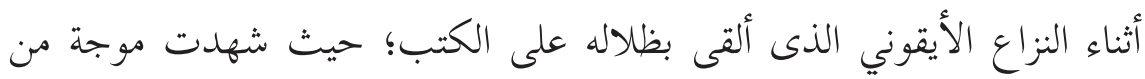

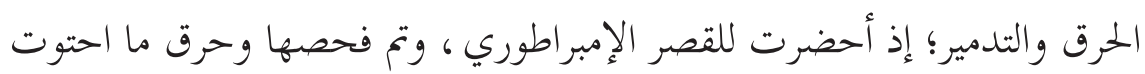

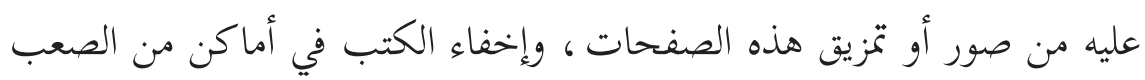

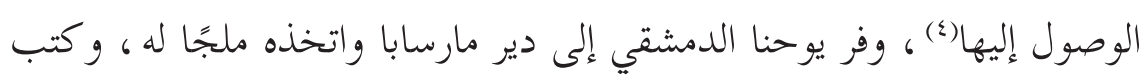
هناك الكثير من أعماله عارض فيها سياسة الدولة الرسمية في ذلك الوقت وفرئ. كذلك مثلت المكتبات الديرية مركز جذب ومزارًا للعديد من المفكرين والأدباء

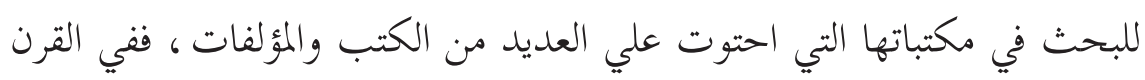

(1) TAlbot, Bluestocking Nuns, p.611; Fryde, Palaeologan Renaissance, p.181.

(2) STAIKos, The History of The Library, p.126.

(3) BAKIRTZIS, Library Spaces in Byzantine, p.44.

(4) Staikos, The History of The Library, p.126.

(5) Staikos, The History of The Library, p.126. 
السادس الميلادي زار القديس يوحنا موسخوس John Moschos ( •00_9 الجم م)

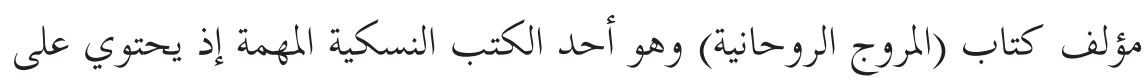

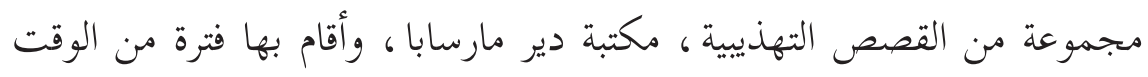

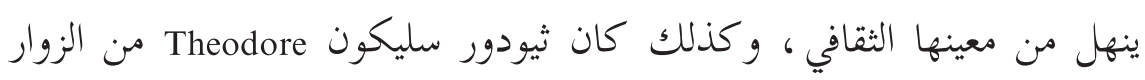

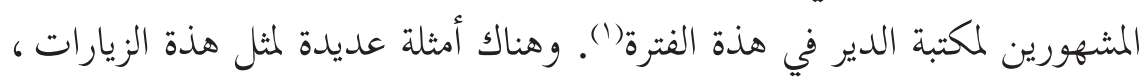

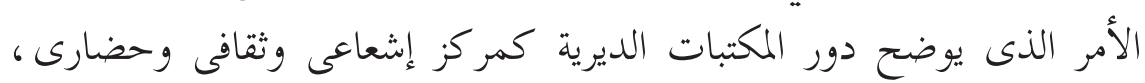

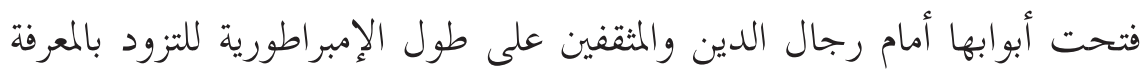

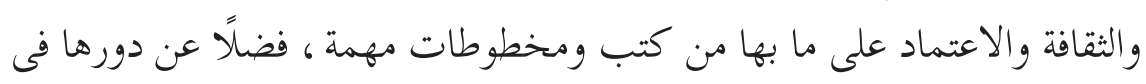
حفظ التراث الكلاسيكي بوجه خاص. بالإضافة إلى ذلك كله يمكن القول بأن المكتبات الديرية قد قامت بدور مهم

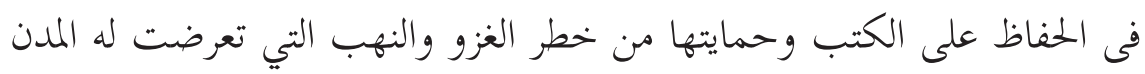

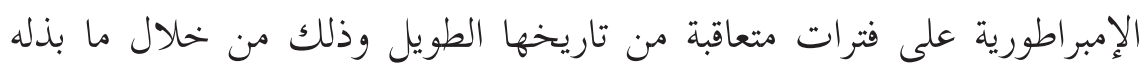

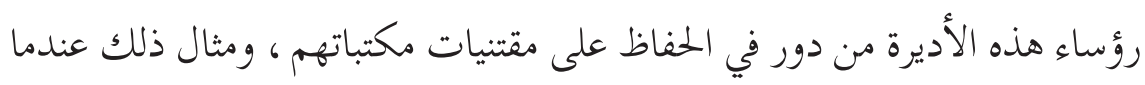

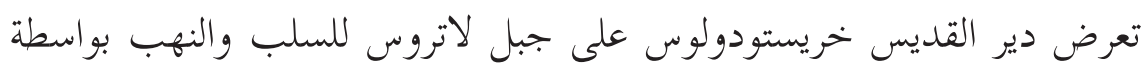

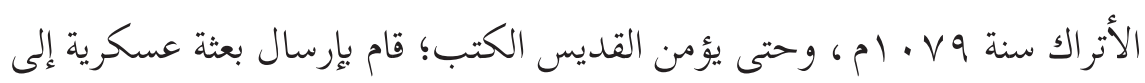

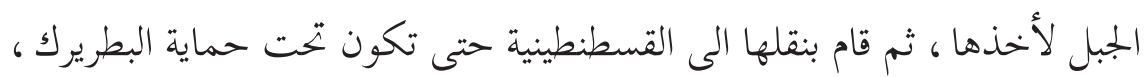

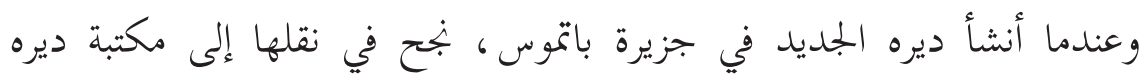

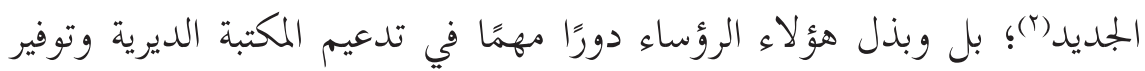

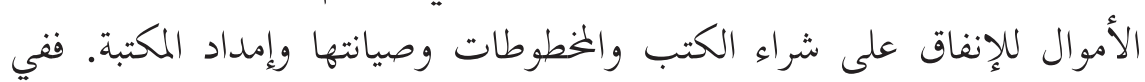

SABAS, pp.1311-1312; PADOVER, (1) سعاد عبد الحميد : التنظيمات الديرية في بيزنطة ، عب؟

Byzantine Libraries, pp.314-315.

(2) Christodoulos, p.599; PAdover, Byzantine Libraries, p.323, Wilson, The Libraries of Byzantine World, p.69. 


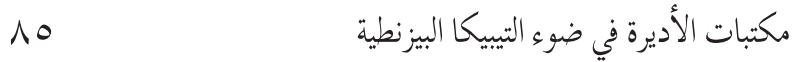

$$
\begin{aligned}
& \text { خطاب أرسله مكسيموس بلانويديس للدمستق ورجل الدولة جورج موزوالون } \\
& \text { George Mouzalon } \\
& \text { الكتب لها و بذل جهدًا كبيرًا في تجديد هذه المكتبة(؟). } \\
& \text { علي هذا النحو يتضح لنا الدور المهم الذي قامت به المكتبات الديرية في الحفاظ } \\
& \text { على التراث الثقافي للحضارة البيزنطية. }
\end{aligned}
$$

\section{قائمة المختصرات}

- B: Byzantion

- BMFD: Byzantine Monastic

- BZ: Byzantinische Zeitschrift.

Foundation Documents.

- EEBS, Epeteris Etaireias Byzantinon Spoudon.

- GRBS, Greek,Roman and Byzantine Studies.

- JA: Journal Asiatique.

- L'CR, Libraries and The Cultural Record.

- ODB, Oxford Dictionary Of Byzantium.

(1) Constantinides, Higher Education, pp.68-9. 
